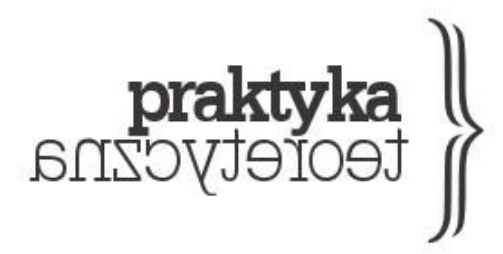

\title{
WPROWADZENIE DO TEORII KAPITALIZMU KOGNITYWNEGO: KAPITALIZM KOGNITYWNY JAKO REŻIM AKUMULACJI
}

\author{
MIKOEAJ RATAJCZAK
}

\begin{abstract}
Abstrakt: Artykul stanowi zarazem historyczne, jak i systematyczne oraz problemowe wprowadzenie do teorii kapitalizmu kognitywnego. Rekonstruuje najważniejsze stanowiska i debaty $\mathrm{w}$ danym polu, od pierwszych publikacji na temat prac niematerialnych oraz postfordyzmu przez analizy kryzysu finansowego 2001 roku po najnowsze publikacje teoretyków i teoretyczek kapitalizmu kognitywnego. Systematyzuje rozproszone w debacie nad kapitalizmem kognitywnym analizy, od wzrastającej roli efektów zewnętrznych i renty we współczesnym kapitalizmie, przez przekształcenia intelektu powszechnego po wykształcenie się nowych form wartości i nowych mechanizmów jej akumulacji. To właśnie to ostatnie zagadnienie, nowe mechanizmy akumulacji wartości, stanowi główny problem, na którym skupia się artykuł. Ukazując funkcje kapitału finansowego w ukształtowaniu się kapitalizmu kognitywnego jako pewnego reżimu akumulacji, artykuł nie tylko analizuje kapitalizm kognitywny jako niestabilny reżim akumulacji, ale stara się w systematyczny sposób przedstawić sprzeczności tegoż reżimu akumulacji.
\end{abstract}

Słowa kluczowe: kapitalizm kognitywny, akumulacja, wartość, kapitał finansowy, praca niematerialna, intelekt powszechny, efekty zewnętrzne, ekonomia polityczna, Vercellone, Marazzi, Moulier-Boutang 
Teoria kapitalizmu kognitywnego, która analizuje ciagłość charakterystycznych dla kapitalistycznej gospodarki relacji podporządkowania i wyzysku siły roboczej w ,gospodarce opartej na wiedzy", stała się już szeroko dyskutowana, choć z pewnością nie bezkrytycznie przyjmowana perspektywą ${ }^{1}$ analizy zachodzących transformacji społeczeństw rozwiniętych oraz globalnego systemu ekonomicznego. Transformacje te sięgaja lat siedemdziesiątych i związane były z końcem powojennego modelu rozwoju kapitalizmu przemysłowego oraz państwa dobrobytu. Były to zmiany niezwykle głębokie, które objęły zarówno bunt kulturalny przeciwko ukształtowanemu po wojnie porządkowi państwowo-gospodarczemu, zwrot w polityce monetarnej Stanów Zjednoczonych (odejście od parytetu złota i wprowadzenie nowej polityki FED w roku 1979), „deindustrializację” lat siedemdziesiątych, rozrost rynków finansowych i przekształcenia dotykające tkanki miast, „globalizację” oznaczająca w dużym stopniu swobodny, międzynarodowy obieg kapitału finansowego, powolny demontaż państwa dobrobytu oraz rozpoczęcie się nowej fali kryzysów globalnego kapitalizmu (od kryzysu naftowego w roku 1973 mieliśmy już do czynienia z około dwudziestoma znaczącymi kryzysami ekonomicznymi). Na ten sam czas przypada również rewolucja technologiczna związana z opracowaniem na początku lat siedemdziesiątych pierwszych mikroprocesorów, które umożliwiły zarówno masową automatyzację procesów produkcyjnych, jak i upowszechnienie komputerów osobistych (lata osiemdziesiąte) i stworzenie globalnej sieci komunikacji między ich użytkownikami (lata dziewięćdziesiąte).

Analiza tej nowej „wielkiej transformacji” - kryzysu powojennego kapitalizmu przemysłowego oraz miniaturyzacyjnej rewolucji technologicznej - była przedmiotem licznych teorii społecznych badających „informacjonizm”, „gospodarkę opartą na wiedzy”, głoszących nastanie „społeczeństwa sieci” czy wręcz „końca pracy” oraz historii. Teoria kapitalizmu kognitywnego, rozwijana od początku XXI wieku, analizuje te zmiany w odniesieniu do kryzysów „gospodarki opartej na wiedzy”, ich strukturalnego powiązania z innymi kryzysami późnego kapitalizmu (w szczególności z obecnym kryzysem finansowym) oraz szerzących się zjawisk outsourcingu, offshoringu, prekaryzacji zatrudnienia oraz pogarszania się ekonomicznej sytuacji nie tylko „kognitariatu”, lecz również pracowników innych sektorów gospodarki. Teoretyczne korzenie teorii kapitalizmu kognitywnego sięgają dwóch

1 Teoria kapitalizmu kognitywnego krytykowana jest najczęściej za przywiązywanie zbyt dużej wagi do roli pracy kognitywnej i pomijanie innych, mniej technologicznie rozwiniętych sektorów pracy i produkcji (zob. Caffentzis i Federici 2011), które to zarzuty wywodzą się ze starszych dyskusji wokół pojęcia „pracy niematerialnej" (Caffentzis 1998). Wśród teoretyków bliskich teorii kapitalizmu kognitywnego wyróżniają się zarzuty założyciela P2P Foundation, Michela Bauwensa, który zamiast o „kapitalizmie kognitywnym” woli mówić o „kapitalizmie netarchicznym”, mającym czerpać wartość dodatkową nie tyle z pracy „masowej inteligencji”, lecz przede wszystkim z pracy w sieciach peer-to-peer (Bauwens i Kostakis 2014). Niemniej najczęstszą i zdecydowanie najsłabszą linią krytyki jest ta, która nie odróżnia teorii kapitalizmu kognitywnego od koncepcji końca pracy, nastania klasy kreatywnej czy różnych wersji „,nowego kapitalizmu” (wśród polskich publikacji zob. Szahaj 2014). 
paradygmatów badawczych: po pierwsze, postoperaistycznej teorii pracy niematerialnej i biopolitycznej, po drugie, metodologii francuskiej szkoły regulacyjnej.

Rozwijane od początku lat dziewięćdziesiątych pojęcie pracy niematerialnej (Negri i Lazzarato 1991; zob. Lazzarato 2010) stanowiło odpowiedź nieortodoksyjnych marksistów, określanych często jako „autonomiści” (Brouillette 2009), na rozwój sektora usług oraz „przemysłów kreatywnych”, które obejmowały relacją pracy najemnej rodzaje działalności wcześniej uznawane za pracę twórczą, aktywność artystyczną itd. W słynnej książce Imperium Michael Hardt i Antonio Negri (2005) jako pracę niematerialną ujęli również pracę opartą na przetwarzaniu informacji i obsłudze maszyn obliczeniowych, łącząc koncepcję pracy niematerialnej z postoperaistycznymi dyskusjami nad Marksowskim pojęciem ,intelektu powszechnego" (Virno 1992). W efekcie krytyki pracy niematerialnej jako pomijającej pracę ciała, afektów, pracę opiekuńczą i reprodukcyjną (zob. Fortunati 2007), Hardt i Negri zaproponowali termin „praca biopolityczna” (Hardt i Negri 2012), która miała obejmować wszystkie efekty produkcji społecznego bios. Zasadnicza różnica między postoperaistycznymi koncepcjami pracy niematerialnej i biopolitycznej a teoria kapitalizmu kognitywnego polega na przyjęciu różnych perspektyw: albo bada się produktywność i wyzysk z perspektywy podmiotów wytwarzających wartość (praca biopolityczna), albo też analizuje się nowy reżim akumulacji, a więc na pracę niematerialną patrzy się z perspektywy wytwarzania i cyrkulacji wartości (kapitalizm kognitywny).

Francuska szkoła regulacyjna dostarczyła odpowiednie narzędzia do teoretycznego opracowania kapitalizmu kognitywnego właśnie jako reżimu akumulacji. W publikacji prezentującej program badań nad kapitalizmem kognitywnym, sformułowany przez kolektyw ISYS (Innovation Systèmes Stratègies) zlokalizowany w Laboratorium Matisse na Uniwersytecie Paryskim I (Corsani et al. 2001)², jego autorzy powołują się na wprowadzoną przez Michela Agliettę różnicę między modelem produkcij, reżimem akumulacji oraz systemem regulacji (Aglietta 1997) jako na adekwatną ekonomiczną metodologię do analizy rozwoju kapitalizmu przemysłowego, którego nie można wytłumaczyć samą rewolucją technologiczną (Corsani et al. 2001, 8). Określony model produkcji (używana technologia, rodzaj wykonywanej pracy, podział pracy itd.) współistnieje z pewnym reżimem akumulacji (systemem podziału wytwarzanej wartości na płace, inwestycje, oszczędności, system ubezpieczeń społecznych itd.), a ich wspólistnienie stabilizuje określony system regulacji o charakterze kulturowopolitycznym, który łagodzi napięcia i antagonizmy wywoływane przez proces akumulacji

2 Artykuł ten oparty jest przede wszystkim na pracach badaczy z tego kolektywu lub współpracujących z nim. Należy jednak zauważyć, że sam termin „,kapitalizm kognitywny” zaproponowany został wcześniej przez Lorenza Cillario (1990; 1991). Wśród autorów, którzy rozwinęli stanowisko bliskie teorii kapitalizmu kognitywnego, należałoby również wymienić prace André Gorza (2010 [2003]) oraz Enzo Rullaniego (2004a; 2004b). Systematyczne badania nad problematyka kapitalizmu kognitywnego sa obecnie jednak prowadzone przede wszystkim w paradygmacie zaproponowanym przez kolektyw Matisse-ISYS. 
kapitału. W tym sensie w szkole regulacyjnej oraz w teorii kapitalizmu kognitywnego mówi się nie tylko o kryzysie kapitalizmu przemysłowego, lecz o przejściu od fordyzmu do postfordyzmu, charakteryzującego się zarówno nowym modelem produkcji, jak również różnym od fordystycznego systemem akumulacji i regulacji (zob. Amin 1994). Czynnikami, które doprowadziły do kryzysu fordyzmu, były: bunty społeczne przeciwko „fordystycznej” organizacji powtarzalnej pracy fabrycznej, niezdolność do zwiększania produktywności kapitału, wzrost kosztów reprodukcji społecznej (przede wszystkim edukacji) i globalny kryzys państwa dobrobytu oraz uformowanie się nowego typu podmiotowości o innych dążeniach i pragnieniach (Corsani et al. 2001, 12), a więc w równym stopniu zmiany w modelu produkcji, jak i w reżimie akumulacji oraz systemie regulacji.

Większość pierwszych tekstów poświęconych kapitalizmowi kognitywnego (np. Terranova 2000; Corsani et. al. 2001; Zanini i Fanini 2001; Marazzi 2008 [2002]; Vercellone 2003) została opublikowana na początku XXI wieku, a więc już po kryzysie dotcomów i „,nowej ekonomii”, a dalsze publikacje powstawały w trakcie kolejnego cyklu akumulacji (od 2003 do 2007 roku) oraz kryzysu finansowego (2007). Dzięki temu teoretyczki i teoretycy kapitalizmu kognitywnego byli w stanie ukazać strukturalną zależność między ,gospodarką opartą na wiedzy" a kolejnymi fazami (które dalej w tekście będziemy nazywać za André Orléanem „konwencjami”) akumulacji kapitału finansowego.

Celem tego tekstu jest wprowadzenie do teorii kapitalizmu kognitywnego przede wszystkim jako teorii nowego reżimu akumulacji. Choć będę również opisywał nowe formy pracy i produkcji, a także zmiany kulturowe (czyli formowanie się „nowego typu podmiotowości”), moim głównym celem jest ukazanie, w jaki sposób wytwarza się, dystrybuuje oraz akumuluje wartość w „gospodarce opartej na wiedzy”. Dlatego też nacisk będę kładł na rolę i funkcję kapitału finansowego w procesie akumulacji w kapitalizmie kognitywnym - główna teza tego tekstu głosi, że wytworzenie się gospodarki, w której podstawowym czynnikiem produkcji jest wiedza i informacja, było napędzane przez postępująca finansjeryzację ${ }^{3}$. Co więcej, to właśnie zależność gospodarki opartej na wiedzy od kapitału finansowego stanowi o fundamentalnej niestabilności reżimu akumulacji kapitalizmu kognitywnego, którego jednym z efektów jest obecny kryzys finansowy.

$\mathrm{Na}$ samym początku postaram się przedstawić główne tezy teorii kapitalizmu kognitywnego, które stanowią jednocześnie krytykę liberalnych koncepcji gospodarki opartej na wiedzy, oraz scharakteryzuję najważniejsze cechy kapitalizmu kognitywnego jako finansowej gospodarki produkecji, w której wzrost, warunek stabilizacji reżimu akumulacji, zależny jest przede wszystkim od inwestycji kapitału finansowego. Następnie zanalizuję kryzys dotcomów jako najważniejszy przypadek napędzania gospodarki opartej na wiedzy przez postępująca

\footnotetext{
3 Przez pojęcie finansjeryzacji należy rozumieć rozwój rynków finansowych, a w wyniku tego całego sektora finansowego, którego dynamika prowadzi do dominacji nad sektorem gospodarki realnej (Dore 2000).
} 
finansjeryzację oraz pokażę zależność obecnego kryzysu finansowego od ideologii „nowej ekonomii” lat dziewięćdziesiątych i bańki internetowej przełomu wieków. Na tym przykładzie pokażę również niestabilność reżimu akumulacji kapitalizmu kognitywnego, a w następnych partiach tekstu postaram się ukazać zmiany, jakie wprowadzono w procesach akumulacji i dystrybucji wartości po kryzysie roku 2000. Będę charakteryzował również najważniejsze czynniki determinujące wytwarzanie wartości w kapitalizmie kognitywnym, takie jak dynamiczne ekonomie sieci (efekty zewnętrzne) oraz „kapitał ludzki” (czyli kapitał stały w nowym organicznym składzie kapitału w kapitalizmie kognitywnym), w uwagach końcowych postaram się zaś krótko opisać funkcje kapitału finansowego w reżimie akumulacji kapitalizmu kognitywnego.

Poza liberalne koncepcje ekonomii opartej na wiedzy - kapitalizm kognitywny jako finansowa gospodarka produkcji

Carlo Vercellone, jeden $\mathrm{z}$ głównych teoretyków pracujących w ramach ISYS, w opublikowanym w 2005 roku referacie The Hypothesis of Cognitive Capitalism postulowa1 odejście od neoklasycznych teorii „ekonomii opartej na wiedzy”, bazujących na endogenicznym modelu wzrostu gospodarczego, a także od wszelkich modeli ograniczających analizę transformacji społecznej do rewolucji informatycznej ${ }^{4}$ Zamiast tego Vercellone podkreślał, że kapitalizm kognitywny oznacza nowy historyczny etap procesu akumulacji kapitału oraz nowy stosunek między kapitałem a praca. Choć relacja ta według Vercellonego od zawsze wyznaczana była przez tych, którzy kontrolują organizacje pracy oraz produktywna wiedzę („duchowe siły produkcji” [Marks 1968, 427]), to trzeci etap historycznego procesu akumulacji kapitału (po kapitalizmie merkantylistycznym oraz kapitalizmie przemysłowym) charakteryzuje się przede wszystkim nowym stosunkiem šywej wiedsy do martwej wiedsy (Vercellone 2005, 6-7). Produktywny rodzaj wiedzy nie jest już oddzielany od pracujących podmiotowości w postaci systemu maszyn oraz narzucanego podziału pracy i jej organizacji, lecz jest inherentny samym tym podmiotowościom, (współ)pracującym w sieciach komunikacji. Stąd mowa u niego o rozproszonej inteligencïi (dalej określimy ją również jako intelekt powsz̧echny) jako nowej postaci produktywnej wiedzy. Ukonstytuowanie się tej heterogenicznej siły roboczej jako głównego czynnika produkcji było efektem trzech społecznych procesów: 1. masowej odmowy pracy przez pracowników w kapitalizmie przemysłowym (bunt nowych pokoleń przeciwko

\footnotetext{
4 Vercellone nie czyni rozróżnień w ramach krytykowanych przez niego teorii gospodarki opartej na wiedzy. Można jednak pokazać, że z jednej strony chodzi o klasyczne sformułowanie znaczenia sektora B\&R oraz inwestycji w innowacyjność, które pojawia się raporcie OECD z roku 1996 (Foray i Lundvall 1996), z drugiej zaś o wszelkie teorie technologicznego determinizmu w rodzaju klasycznego już neoschumpeterianizmu (Freeman i Perez 1988), łączącego pojęcie innowacji Schumpetera oraz teorię cykli Kondratiewa. Moulier-Boutang umieszcza między tymi dwoma podejściami również teorię społeczeństwa sieci (Moulier-Boutang 2011, 39-41).
} 
fordystycznemu modelowi produkcji), 2. rozprzestrzenienia się wiedzy w społeczeństwie w wyniku umasowienia szkolnictwa wyższego oraz 3. rozwoju państwa dobrobytu, które dzięki szerokiej ofercie świadczeń społecznych zmniejszyło nacisk ekonomiczny wywierany przez rynek, umożliwiając coraz większej części pracującej populacji poszukiwanie alternatywnych form aktywności i zarobku, często związanych z szeroko rozumianą pracą twórczą (Vercellone 2005, 7-8). Uformowanie się rozproszonej inteligencji można ują́ jako rozwój dynamicznych gospodarek opartych na uczeniu się wraz z dynamicznymi gospodarkami sieci (Fumagalli i Lucarelli 2014, 88-89). Te dwie dynamiczne ekonomie skali, których rozwój był ściśle związany z nowymi technologiami informatycznymi i komunikacyjnymi, wyznaczały zmianę sposobu funkcjonowania wiedzy jako czynnika produkcyjnego: celem nie było już tylko, jak w fordystycznych statycznych ekonomiach skali, zmniejszenie kosztu krańcowego i zwiększenie wydajności na drodze aplikowania technologicznych innowacji do kapitału trwałego (maszyn fabrycznych), lecz wykorzystywanie zdolności i umiejętności pracowników przez angażowanie ich w proces produkcji, inwestycje w „kapitał ludzki” i w innowacyjne metody zarządzania procesem produkcji, przedsiębiorstwem oraz jego relacjami z rynkiem, co oznaczało gwałtowny wzrost znaczenia zdolności pracy z informacjami i danymi oraz kompetencji „miękkich”.

Ujęcie to unika dwóch zasadniczych błędów teorii ekonomicznych mierzących się z nowa rola wiedzy w gospodarce: 1) redukowania jej do nowej subdyscypliny ekonomicznej, która nie zmieniałaby wiele w ogólnym makroekonomicznym modelu oraz 2) tworzenia modeli nowej „gospodarki opartej na wiedzy”, zrywających ze stosunkami społecznymi, które cechowały poprzednie systemy gospodarcze (Lucarelli i Vercellone 2013, 3-4). Zamiast tego umożliwia ono badanie nowych antagonizmów w gospodarce, w której głównym czynnikiem produkcji staje się wiedza ucieleśniona w wielości podmiotów. Z jednej strony społeczny proces produkcji wymaga swobodnego dostępu do wiedzy jako podstawowego czynnika produkcyjnego, a więc możliwości korzystania z odpowiedniego sprzętu (hardware), odpowiednio skodyfikowanej w cyfrowej postaci wiedzy (software), społecznotechnologicznego zaplecza gwarantującego efektywność komunikacji sieciowej (netware) oraz wykształconych dyspozycji pracujących podmiotowości (wetware) (Moulier-Boutang 2011, 53). Z drugiej strony proces akumulacji kapitału wymaga podtrzymania i kontroli „,cyklu życiowego wiedzy” (Fumagalli i Lucarelli 2010, 12), czyli przechodzenia od wiedzy milczącej do wiedzy skodyfikowanej i do wiedzy wyzyskiwanej w procesie pomnażania wartości. Produktywność ucieleśnionej, ṡywej wiedzy musi bowiem być produktywna dla kapitału, a zatem efekty jej aktywności muszą przekładać się na mierzalne zyski dla inwestorów. Warunkami funkcjonowania ekonomii uczenia się są efektywność, kumulatywność oraz wywłaszczalność wiedzy (Fumagalli i Lucarelli 2014, 87-88), a więc możliwość akumulowania wytwarzanej przez żywą wiedzę wartości użytkowej oraz wymiennej. Na tym tle powstają społeczne antagonizmy, 
takie jak sprzeciw wobec postępującej prywatyzacji sektorów niezbędnych do wytworzenia „wiedzy milczącej” (instytucji edukacji), kodyfikowania niektórych rodzajów wiedzy (DNA, danych osobowych itd.) oraz narzucania relacji własności na coraz to nowe postaci skodyfikowanej wiedzy. Społeczny proces produkcji wiedzy wymaga nie tylko swobodnego dostępu do wiedzy skodyfikowanej, lecz również do podstawowych zasobów kognitywnej pracy - uwagi oraz czasu. Walka o te zasoby wprowadza kolejny rodzaj antagonizmu: sposoby ich mierzenia w odniesieniu do pracy kognitywnej różnią się zasadniczo od mierzenia czasu pracy wykonywanej w ramach produkcji przemysłowej. Konflikty społeczne rodzą się zatem zarówno na tle ograniczania dostępu do skodyfikowanej wiedzy (ograniczanych przez prawa własności intelektualnej), jak i do zasobów uwagi (ograniczanych przez koszty reprodukcji społecznej).

Podstawową różnicą między teorią kapitalizmu kognitywnego a liberalnymi teoriami ekonomii opartej na wiedzy jest ujęcie obecnych stosunków produkcji w sektorach usługowych, high-tech, B\&R, przemysłów kreatywnych, spółek internetowych, start-upów itd. jako relacji antagonistycznych: $z$ jednej strony tendencji do korzystania ze swobodnej cyrkulacji wiedzy i informacji, z drugiej strony tendencji do wytwarzania wartości dodatkowej z pracy wiedzy żywej i cyrkulacji wiedzy martwej. Z perspektywy teorii kapitalizmu kognitywnego rozwój nowych modeli produkcji należy traktować jako ewolucję stosunków produkcji w ramach społeczeństwa kapitalistycznego, jako wykształcenie się nie tylko nowych możliwości rozwoju i przestrzeni wolności, ale także metod wyzysku i akumulacji kapitału przekształcających w sposób radykalny społeczeństwo jako całość (Vercellone 2007).

Kapitalizm kognitywny jest „reżimem akumulacji bez realizowalnego sposobu regulacji między przedsiębiorcami i pracownikami w odniesieniu do wyzyskiwania wiedzy i alokacji zysków kapitałowych" (Fumagalli i Lucarelli 2010,10). Z jednej strony stanowi on efekt polityki społecznej państwa dobrobytu, z drugiej zaś podważa stosunki społeczne, które stanowiły ekonomiczną bazę tego państwa: warunkiem akumulacji wiedzy są wysokie inwestycje zarówno w B\&R, jak i w kapitał ludzki, prywatne przedsiębiorstwa są zaś beneficjentami aktywności rozproszonej inteligencji, niekoniecznie ponosząc koszty jej funkcjonowania czy inwestycji w nia. Korzystając z rozproszonej wiedzy milczącej, podmioty prywatne dążą do objęcia efektów globalnej produkcji wiedzy („efekty zewnętrzne”) prawami własności oraz do prekaryzacji zatrudnienia. Fumagalli i Lucarelli (2007) ujęli te zależności w formie makroekonomicznego modelu, zgodnie z którym wzrost produktywności zależny jest od ograniczającego efektu narzuconych praw własności intelektualnej (w im mniejszym stopniu ograniczają one cyrkulację wiedzy, tym wyższa jej produktywność) ${ }^{5}$ oraz skłonności kapitału finansowego do inwestycji w ekonomie sieci oraz uczenia się, która zależna jest od wyników

\footnotetext{
${ }^{5}$ Fumagalli i Lucarelli ujmują to krótko: „tam, gdzie gospodarki sieciowe są istotniejsze od praw własności intelektualnej w oddziaływaniu na wzrost wydajności, stopa wydajności zawsze rośnie” (2014, 91).
} 
poprzednich inwestycji tego rodzaju (Fumagalli, Lucarelli 2007, 126). Włoscy ekonomiści twierdza, że nawet biorąc pod uwagę znaczenie inwestycji sektora publicznego oraz rozwój statycznych gospodarek skali (chociażby tych wytwarzających hardware), wzrost w kapitalizmie kognitywnym jest determinowany przede wszystkim przez inwestycje (i zyski z tych inwestycji) w czynniki produkcji wiedzy dokonywane przez swobodnie cyrkulujący kapitał finansowy (nastawiony na inwestycje przynoszące szybki i wysoki zysk). Kapitalizm kognitywny można zatem określić jako finansowa gospodarke produkciji.

Przy założeniu, że warunkiem stabilności reżimu akumulacji jest ciagły wzrost zatrudnienia, w kapitalizmie kognitywnym jako finansowej gospodarce produkcji inwestycje i konsumpcja na bazie zysków z inwestycji kapitału finansowego muszą być większe od poziomu konsumpcji wynikającego z płac (Fumagalli i Lucarelli 2007, 127). Ta zależność stabilności reżimu akumulacji kapitalizmu kognitywnego od kapitału finansowego wykształciła się w latach dziewięćdziesiątych w ramach boomu „nowej ekonomii”, kiedy ciągły wzrost giełdowej wartości spółek internetowych i generalnie całego sektora high-tech przynosił olbrzymie zyski z inwestycji venture capital. Warunkiem możliwości uformowania się nowej ekonomii była zachodząca od połowy lat siedemdziesiątych prywatyzacja funduszy ubezpieczeń społecznych i emerytur, która nie tylko uzależniła egzystencję wielu grup społecznych od wahań sektora finansowego, lecz również uwolniła olbrzymie ilości wartości i umożliwiła inwestowanie ich na coraz mniej regulowanych i kontrolowanych rynkach finansowych (Marazzi 2014b). Prywatyzacja funduszy społecznych nie tylko naruszała jeden z podstawowych mechanizmów regulujących reżim fordystyczny, lecz również utorowała drogę do wykształcenia się gospodarki opartej na wiedzy jako finansowej gospodarki produkcji.

W nowo ukształtowanym reżimie akumulacji brakuje jednak systemowego mechanizmu regulacji:

\begin{abstract}
bez sposobu regulacji gwarantującego, iż całość wyprodukowanego bogactwa będzie ponownie zainwestowana w dynamiczne ekonomie uczenia się i sieci, oraz bez polityki kontrolującej powstawanie baniek spekulacyjnych wzrost na bazie inwestycji finansowych jest cały czas zagrożony niestabilnością (Fumagalli i Lucarelli 2007, 128).
\end{abstract}

Wymienione wcześniej antagonizmy, cechujące stosunki społeczne w kapitalizmie kognitywnym, skutecznie uniemożliwiają wprowadzenie takiego sposobu regulacji. Z jednej strony mamy bowiem sieci kooperacji, często o różnym statusie (od przedsiębiorstw działających w sieci przez nieformalne kolektywy artystów lub programistów po miliony osób korzystające z Internetu), dla których warunkiem dalszego rozwoju działalności jest możliwość nieekskluzywnego kumulowania, przyswajania i korzystania z wiedzy. Z drugiej zaś mamy podmioty inwestujące w innowacje i wiedzę, które to inwestycje „charakteryzują się bardzo 
wysoką potencjalną rentownością i jednocześnie możliwymi katastrofalnymi stratami” (Fumagalli i Lucarelli 2010, 15). Jako że inwestycje te dokonywane są w dużym stopniu przez kapitał finansowy, niezbędne okazuje się wprowadzenie kryteriów i norm, które posłużą do mierzenia przychodów z inwestycji. Trzeba pamiętać, że efekty inwestycji w innowacje i wiedzę moga przybrać niespodziewany rezultat, lub też ich efekty mogą wpłynąć pozytywnie na ekonomie sieci, lecz być trudno kodyfikowalnymi i w efekcie nie przynosić mierzalnych finansowo zysków.

\section{Od kryzysu dotcomów do kryzysu finansowego}

Najlepszym studium przypadku niestabilności kapitalizmu kognitywnego była „bańka internetowa" i kryzys roku 2000. W okresie między rokiem 1993 a rokiem 2000 Nowojorska Giełda Papierów Wartościowych zanotowała olbrzymie wzrosty (Dow Jones z 4000 do 11700 , Standard \& Poor's z 450 do 1530), które były zasadniczo efektem stałych inwestycji w sektor high-tech, przede wszystkim w tzw. dotcomy. Widać to głównie po indeksie NASDAQ Composite (NASDAQ jest rynkiem akcji, na którym funkcjonowała wówczas większość spółek internetowych`), który w 1991 roku przekroczył 500 punktów, w 1995 osiagną̨ ponad 1000 punktów, by w 2000 roku osiagnaćć rekordowe 5132,52 punktów. Inwestycje rynków finansowych katalizowały powstawanie nowych form organizacji pracy kognitywnej, faworyzujących swobodną organizację pracy (Fumagalli i Lucarelli 2010, 17) - stary model przedsiębiorstwa uznano za przeżytek, a na jego miejsce pojawiały się różnego rodzaju „firmy sieciowe", które eksperymentowały z formami zatrudnienia. Jak podkreśla André Orléan, jeden z głównych przedstawicieli teorii regulacji, ten wzrost na bazie inwestycji finansowych napędzany był dodatkowo duchem „społeczeństwa cyfrowego”, uwolnienia się od ograniczeń starego modelu gospodarczego i wkroczenia kapitalizmu na drogę nieograniczonego wzrostu niezagrożonego kryzysami (Orléan 2012, 10). Można powiedzieć, że w okresie tym uformowała się pewna stabilizacja systemu gospodarczego, która była przede wszystkim efektem aktywności rynków finansowych. Rynki te działały zgodnie z panującymi wówczas konwencjami regulującymi zachowania inwestorów: dłuższy okres braku kryzysów finansowych, stabilna stopa wzrostu, upadek Związku Radzieckiego oraz rozwój nowych technologii komunikacyjnych ukształtowały powszechną wiarę w nieograniczone możliwości nowej gospodarki cyfrowej, co przekładało się wprost na zachowania rynków finansowych.

Konwencja nie ma jednak charakteru wyłącznie kulturowego, lecz musi też umożliwiać monetyzację - przełożenie aktywów (inwestycji) na pieniądze. Potężna siła kapitału

6 Co więcej, giełda NASDAQ była też pierwszą, która wprowadziła możliwość kupowania i sprzedawania akcji online. 
finansowego zależy przede wszystkim „od jego zdolności do narzucenia kryterium finansowych zysków" (Fumagalli i Lucarelli 2010, 22). To właśnie miało miejsce w przypadku rewolucji cyfrowej lat dziewięćdziesiątych i kryzysu roku 2000. Większość biznesów w stylu dotcom przynosiła straty z czysto finansowego punktu widzenia, przez co niezbędne było wprowadzenie nowych form wyceny wartości danego przedsięwzięcia, takich jak chociażby „klikalność” czy „value per user” (Orléan 2012, 10). Niemniej inwestycje w zaawansowane technologicznie przedsięwzięcia okazały się dla firm efektywne - jeszcze w 2000 roku firmy, które inwestowały w zaawansowane technologie, zanotowały wzrost produktywności rzędu 13,4\%, a firmy, które nie dokonywały takich inwestycji - rzędu 4,9\% (Marazzi 2008, 70). Warto podkreślić, że przez całą druga połowę lat dziewięćdziesiątych można było zaobserwować wzrost produktywności niewidziany w krajach rozwiniętych od 25 lat - średni roczny wzrost produktywności od 1995 roku do momentu kryzysu wynosił 2,4\%. Reagując na kryzys, ówczesny przewodniczący FED, Alan Greenspan, stwierdził jednak, że wzrost ten był tylko pozorny.

Należy przyjrzeć się tej pozorności. Stefano Lucarelli twierdzi, że w reżimie akumulacji, który narodził się w drugiej połowie lat dziewięćdziesiątych, najważniejsze było wytworzenie nowych form wynagrodzenia, ściśle powiazzanych z całym rynkiem finansowym. Było to efektem całkowitej zmiany w strukturze wprowadzania innowacji w gospodarce:

\begin{abstract}
dźwignia innowacji przeszła z laboratoriów $B \& R$ na żywe ciała siły roboczej, podczas gdy kapitał z całej reszty świata był inwestowany w akcje i obligacje biznesowe indeksowane na amerykańskich rynkach. W tym systemie akumulacji rozwinęły się różne formy wynagrodzenia powiązane z wydajnością przedsiębiorstw: nie tylko opcje na akcje dla menadżerów, lecz również fundusze emerytalne i inwestycyjne, które angażowały pracowników najemnych (inwestując ich oszczędności - dop. MR). Te formy wynagrodzenia prowadziły do zwiększenia płynności rynków finansowych, ale przy braku adekwatnej zasady redystrybucji (...) prowadziło to również do zmniejszenia płac, czego efektem była systemowa niestabilność (Lucarelli 2010, 132).
\end{abstract}

Warunkiem tego, by nowe formy wynagrodzenia związane $z$ finansowymi inwestycjami w spółki internetowe miały za swój efekt ciagły wzrost gospodarczy, była konwencja zakładająca, że emitowane akcje mają daną wartość. Brak stabilnego systemu regulacji doprowadził jednak do tego, że gdy nastapiło załamanie giełdy, rynek finansowy, by utrzymać rentowność olbrzymich inwestycji, zainicjował gruntowną reorganizację zatrudnienia (Fumagalli i Lucarelli 2010, 18). Wprowadzono wówczas na masową skalę takie procesy jak downsizing, offshoring, outsourcing itd., które umożliwiły dalszą emisję akcji i zachęcanie inwestorów do ich kupowania, lecz prowadziły jednocześnie do zmniejszenia płac oraz zwiększenia prekaryzacji. Zależność płac i warunków zatrudnienia pracowników od 
finansowych inwestycji w nowe technologie umożliwiła w momencie kryzysu odebranie im tych aktywów lub ich znaczące zmniejszenie (Lucarelli 2010, 133).

Zgodnie z makroekonomicznym modelem kapitalizmu kognitywnego dalszy rozwój w tej sytuacji byłby niemożliwy, gdyby rynki finansowe nie znalazły nowego obszaru inwestycji. Inwestycje te okazały się możliwe dzięki jednoczesnemu przystąpieniu Chin do WTO w 2001 roku, a więc wkroczeniu Państwa Środka do globalnej gospodarki, oraz obniżeniu przez FED stóp procentowych z 6\% do 1\% (Fumagalli i Lucarelli 2010, 18-20). Z jednej strony gospodarka Chin otworzyła nieznane dotąd możliwości przed zagranicznymi inwestorami, którzy mogli teraz dokonywać outsourcingu i offshoringu do kraju o bardzo niskich kosztach pracy, a wzrastający eksport Chin finansował zadłużenia amerykańskiej gospodarki, dzięki czemu rynki finansowe odzyskały płynność. Z drugiej zaś drastyczne obniżenie stóp procentowych przez FED umożliwiło wzrost konsumpcji na bazie pożyczek hipotecznych. Zazwyczaj obniżanie stóp procentowych ma na celu ułatwienie firmom zaciagania kredytu, które to środki firmy przeznaczają na inwestycje. W przypadku sytuacji po kryzysie 2000 roku mechanizm wyglądał inaczej - nowa konwencja „mieszkaniowa” doprowadziła do inflacji cen nieruchomości, co przy niskich stopach procentowych oznaczało, że oprocentowanie kredytów hipotecznych było niższe od wzrostu cen nieruchomości. Konwencja ta była drugim źródłem odzyskania przez rynki finansowe płynności i dała podstawę do rozwijania działalności spekulacyjnej. Kryzys trwający od września 2007 roku jest bezpośrednim skutkiem reakcji na kryzys roku 2000. W obszarze firm internetowych oraz high-tech następuje zaś reorganizacja w strukturze przedsiębiorstw, używanych technologii oraz koncepcji produktu, której milowymi krokami będą np. wprowadzenie iPoda oraz iPhone’a czy rozwój Web 2.0.

\section{Kapitalizm kognitywny jako niestabilny reżim akumulacji}

Należy bliżej przyjrzeć się strukturalnemu powiązaniu niematerialnego charakteru modelu produkcji ${ }^{7} \mathrm{w}$ kapitalizmie kognitywnym $\mathrm{z}$ równie niematerialnym charakterem regulacji reżimu akumulacji. Niematerialny charakter produktów opartych na przetwarzaniu i zarządzaniu informacją wymusza nieustanne innowacje w zasadach określania ich wartości dla inwestorów ${ }^{8}$.

7 „Niematerialny” oznacza tutaj, że angażuje w równym stopniu hardware, software, netware oraz wetware. Należy pamiętać, że koszty wytworzenia hardware są jak najbardziej materialne: wyprodukowanie jednego laptopa wymaga spalenia ok. 250 kilogramów paliw kopalnych i 25 kilogramów chemikaliów oraz zużycia ok. 1,5 tony wody (zob. http://www.nrdc.org/living/stuff/your-computers-lifetime-journey.asp).

8 Oczywiście powstaja wciąż próby wytłumaczenia nierealnej waloryzacji akcji dotcomów podczas bańki lat dziewięćdziesiątych z czysto neoklasycznej perspektywy. Pastor i Veronesi w swoim artykule (2006), broniąc hipotezy efektywnych rynków finansowych, twierdzą na przykład, że wartość akcji danej firmy na giełdzie wzrasta wraz z rosnącą niepewnością co do jej przyszłej wartości. W ten sposób wyjaśniaja gigantyczne wzrosty wartości akcji spółek internetowych w latach dziewięćdziesiątych - w im mniejszym stopniu można było przewidzieć wartość ich akcji, tym większą osiagały one cenę. 
Tym, co jednocześnie determinuje i stabilizuje te innowacje, są właśnie rządzące zachowaniami rynków finansowych konwencje. Konwencje te funkcjonują w oparciu o te same technologie i formy działania, które wyznaczają modele pracy i produkcji w kapitalizmie kognitywnym: maja z jednej strony charakter jesyykowy, są efektami kumulacji wielości performatywów językowych, z drugiej zaś ich efektywność gwarantowana jest wysokim poziomem komputeryzacji giełd na całym świecie, dzięki czemu jednoczesny przepływ informacji i ich obliczanie jest w stanie generować globalne efekty w czasie rzeczywistym (Pasqualle 2014, 101-139).

$\mathrm{Na}$ rynkach finansowych celem konwencji jest przede wszystkim gwarantowanie plynności. Christian Marazzi podkreśla, że plynność to wpierw pewne pojęcie wspólne, które podziela grupa inwestorów przekonana, że dana inwestycja się opłaci, później dopiero zyskuje konkretną funkcję pieniężną (Marazzi 2008, 24). Funkcja pieniężna konwencji polega na tym, że „polityka pieniężna w reżimie napędzanym inwestycjami finansowymi musi podążać za potrzebami waloryzacji wspierającymi konwencje” (Lucarelli 2010, 130), co oznacza, że konwencje określające długookresowe zachowania rynków finansowych determinują kreację pieniądza (z czym mieliśmy do czynienia zarówno w wypadku bańki dotcomów, jak i obecnego kryzysu finansowego). Wykształcenie się jednocześnie modelu produkcji opartego na niematerialnej produkcji oraz niestabilnego reżimu akumulacji opartego na inwestycjach kapitału finansowego, regulowanego konwencjami i pozbawionego stabilnego systemu redystrybucji zysków napędzało globalną gospodarkę od kryzysu fordyzmu aż do obecnego kryzysu finansowego na drodze wykształcania kolejnych konwencji (konwencja „społeczeństwa internetowego”, konwencja „nowej ekonomii”, konwencja „chińska”, konwencja „mieszkaniowa”). Mówiąc inaczej, „krach roku 2001 nie tyle znaczył koniec nowej ekonomii, lecz raczej jej rekalibracje”" (Terranova 2010,155) - kolejne fazy rozwoju kapitalizmu kognitywnego (boom nowej ekonomii 1993-2000, reakcja na kryzys 2000-2003 i bańka na rynku nieruchomości 2003-2007) „,pojawiają się w tym samym paradygmacie technologicznym, ponieważ konwencje, które regulują finansową waloryzację, nie poddają się gwałtownym zmianom" (Lucarelli 2010, 130-131). Jak podkreśla Marazzi, finansjeryzacja nie stanowi nieproduktywnego efektu nagromadzonej wartości dodatkowej, lecz jest wtaściwa forma akumulacji kapitatu dla modelu produkcji keapitalizmu kognitywnego (Marazzi 2011, 48).

Kapitalizm kognitywny to niestabilny reżim akumulacji, który napędzany jest inwestycjami kapitału finansowego kierującymi się dominującymi konwencjami oraz któremu brakuje stabilnego systemu redystrybucji zysków. Zostało to ujęte przez Fumagallego i Lucarellego w makroekonomicznym modelu kapitalizmu kognitywnego: wzrost gospodarczy w kapitalizmie kognitywnym wymaga, by zyski z inwestycji kapitału finansowego były większe od konsumpcji na bazie płac. Przy jednoczesnym braku jakiegokolwiek mechanizmu gwarantującego reinwestycję tych zysków prowadzi to do proliferacji eksperymentalnych form zatrudnienia odchodzących od modelu stałej płacy, niezależnej od aktualnych przychodów 
przedsiębiorstw. Wykształcony w latach dziewięćdziesiątych reżim akumulacji kapitalizmu kognitywnego funkcjonował w postaci niejako „czystej” przede wszystkim w Stanach Zjednoczonych. Dla dalszych badań niezbędne wydaje się porównanie tego reżimu z innymi wersjami „gospodarek opartych na wiedzy”, które rozwinęły się w Europie (zob. Jovanowska i Nikolovska 2010) czy Azji. Wśród czynników, które sprawiły, że model amerykański okazał się determinujący dla globalnej gospodarki, najistotniejsze było z pewnością napędzanie nowej ekonomii w USA przez inwestycje kapitału finansowego i zadłużanie się amerykańskiej gospodarki u krajów z nadwyżką eksportową, które niejako „finansowały” rozwój gospodarki opartej na wiedzy w USA. Ten aspekt teorii kapitalizmu kognitywnego łączy wyjaśnianie dominacji amerykańskiej wersji kapitalizmu kognitywnego z kształtowaniem się w ostatnich dekadach modelu centrum-peryferie: olbrzymie ilości kapitału, zamiast być inwestowane z powrotem w gospodarkę krajów rozwijających się (głównie krajów azjatyckich) i generować popyt, były inwestowane w amerykańskie akcje i obligacje, przez co amerykańskie giełdy dysponowały niekończącą się, aż do pewnego momentu, płynnością (Marazzi 2011, 71). Obecnie stabilizowanie systemu, będącego efektem nowego („kognitywnego”) globalnego podziału pracy, jest możliwe dzięki operacjom finansowym napędzanym głównie drobnymi oszczędnościami oraz wysokim wzrostem gospodarczym w krajach rozwijających się, do których outsoursuje się pracę manualną i fabryczną (Fumagalli i Lucarelli 2014, 89). Dzięki tym warunkom amerykańskie firmy łączące w swojej działalności technologie cyfrowe i komunikacyjne $\mathrm{z}$ operowaniem konwencjami kulturowymi są w stanie akumulować niewyobrażalne wcześniej ilości kapitału finansowego. Dla przykładu, Apple zostało największą w historii USA firmą pod względem jej wartości giełdowej (Browning, Russolilo i Vascerallo 2012), choć zatrudnia jedynie niewiele ponad 90 tys. etatowych pracowników9 Facebook zaś (a także, choć w mniejszym stopniu, LinkedIn) znacząco wpłynął na nowy cykl akumulacji po 2007 roku - od momentu wypuszczenia przez firmę Zuckerberga akcji w roku 2012 indeks NASDAQ regularnie wzrasta, zbliżając się powoli do poziomu z roku $2000^{10}$.

Z pewnościa charakterystyczna dla modelu amerykańskiego różnorodność form wynagrodzenia siły roboczej, wszechobecne zapośredniczenie jej dobrobytu w aktywności rynków finansowych, postępująca prekaryzacja intelektualnej siły roboczej oraz zależność innowacji od inwestycji kapitału finansowego nie są spotykane w tym samym stopniu na całym świecie, niemniej w wyjaśnieniu obecnego kształtu globalnego reżimu akumulacji w kapitalizmie kognitywnym to właśnie ten model należy przyjąć jako paradygmatyczny.

9 Dane na rok 2014, zob. http://www.statista.com/statistics/273439/number-of-employees-of-applesince-2005/. Dla porównania, General Motors w roku 2014 zatrudniało ok. 215 tys. pracowników etatowych.

10 Dane za: http://stockcharts.com/freecharts/historical/nasdaq1978.html. 


\title{
Efekty zewnętrzne i powrót renty
}

Christian Marazzi twierdzi, że finansjeryzacja gospodarek krajów rozwiniętych w latach osiemdziesiątych była strategia nakierowaną na przywrócenie wysokiej rentowności (Marazzi 2011, 31-31). W ramach określonego organicznego składu kapitału11, osiagniętego przez kraje uprzemysłowione pod koniec fordyzmu, dalsza produkcja wartości dodatkowej była mocno utrudniona. W takiej sytuacji inwestycje kapitału finansowego nakierowane na zwiększenie zysków polegały na inwestycji poza bezpośredni proces produkciji:

\begin{abstract}
Nastąiła transformacja procesu waloryzacji polegająca na tym, że ekstrakcja wartości nie jest już ograniczona do miejsca przeznaczonego do produkcji dóbr i usług, lecz rozciaga się poza drzwi fabryki, by użyć takiego sformułowania, w sensie bezpośredniego wkroczenia w sferę cyrkulacji kapitału, to znaczy w sferę wymiany dóbr i usług. Jest to kwestia rozciagnięcia procesu ekstrakcji wartości na sferę reprodukcji i dystrybucji (Marazzi 2011, 48).
\end{abstract}

Inwestycje wspierające wzrost w kapitalizmie kognitywnym sa najczęściej nakierowane na objęcie tych obszarów życia, które tradycyjnie pozostawały poza sfera pracy i funkcjonowały jako efekty zewnetrzne, zgodnie $z$ definicją sformułowaną w latach trzydziestych przez Arthura Pigou (wykonywanie usługi dla osoby trzeciej, za którą nie pobiera się opłaty i która nie może być podstawą do rekompensaty). Pojęcie efektów zewnętrznych stanowi w teorii kapitalizmu kognitywnego zapożyczenie, swego rodzaju præechwycenie terminu $\mathrm{z}$ klasycznej teorii ekonomicznej w celu opracowania i wyjaśnienia zachodzących obecnie transformacji makroekonomicznych. „Efekty zewnętrzne” wprowadzone zostały do ekonomii przez Alfreda Marshalla, który pisał o korzyśsciach zewnętrznych (external economies), przez co rozumiał wkład pozaekonomicznych czynników do wzrostu gospodarek przemysłowych. Tak ujmowane efekty zewnętrzne to przede wszystkim warunki środowiska naturalnego, które wpływają na produkcję i dystrybucję, zmniejszają lub zwiększają koszty itd. Efektami takimi może też być specyficzna kultura danego regionu, sprzyjająca wytężonej i sumiennej pracy, bądź też utrudniająca dyscyplinowanie siły roboczej. Francuski ekonomista André Vianes za efekty zewnętrzne uznał również efekt aktywności instytucji publicznych, które działaja bez nakierowania na zysk, ale tworzą instytucjonalne warunki do rozwoju biznesu (np. dobre lub złe prawo) (Moulier-Boutang 1996). Jego koncepcja „publicznych efektów zewnętrznych”

11 „Organiczny skład kapitału” to termin techniczny oznaczający stosunek kapitału stałego (środków i materiałów produkcji) do kapitału zmiennego (płac); jego formalny zapis przyjmuje zatem postać „c/v”. Im mniejszy udział płacy roboczej w procesie produkcji, tym wyższy organiczny skład kapitału. Zgodnie z Marksowskim twierdzeniem o spadającej stopie zysku, rozwój kapitalizmu przemysłowego ma tendencję do podwyższania organicznego składu kapitału, co jednak przekłada się na spadek stopy zysków i prowadzi do kryzysu. 
stworzona na początku lat osiemdziesiątych wyznacza punkt graniczny między „klasycznym” rozumieniem efektów zewnętrznych jako rzeczywiście zewnętrznych wobec procesu produkcji a efektami zewnętrznymi jako produkcją warunków do odpowiedniego przebiegu procesu produkcji wartości dodatkowej12. Z perspektywy makroekonomicznej na nową rolę efektów zewnętrznych jako bezpośrednich czynników produkcji wskazał Michel Aglietta, który opracował koncepcje „kolektywnych czynników produkcji”, a więc wszystkich tych czynników, które uczestniczą w procesie produkcji niezależnie od rynkowych czy państwowych struktur organizacji (Aglietta 1997) ${ }^{13}$.

Przejście od fordyzmu do postfordyzmu oraz uformowanie się kapitalizmu kognitywnego charakteryzowało się przede wszystkim gwałtownym rozwojem sieci komunikacji, które umożliwiły kooperację jednostek niezwiązanych ze sobą w żaden inny sposób. Wystarczał komputer osobisty, dostęp do Internetu i motywacja - niekoniecznie ekonomiczna. Słynna książka Yochaia Benklera Bogactwo sieci z 2006 roku (Benkler [2006] 2008) stanowi zapis rozwoju aktywności produkcyjnej w sieciach opartych na swobodnej i wolnej wymianie danych. Benkler pokazuje, jak ruch wolnego oprogramowania, ale także np. badania w ramach programu SETI, korzystające z mocy obliczeniowej milionów komputerów osobistych na całym świecie, osiagaja niespotykany wcześniej poziom produktywności. Motywacją do pracy milionów osób współtworzących ruch open source, tworzących Wikipedię itd. nie jest często korzyść ekonomiczna, lecz sama satysfakcja z kognitywnej pracy. Również w sferach, w których nie liczy się tak bardzo moc obliczeniowa, ale raczej wymiana wiedzy milczącej i nieformalnej, sieć komunikacji jest jednym z najważniejszych elementów procesu wytwarzania wartości, a zawiązywanie tych sieci napędzane jest wielością afektów, które na pewno nie moga być wytłumaczone w ramach teorii homo economicus. Z filozofii Deleuze’a i Guattariego (Bednarek 2011) wiemy, że sieci powstają w sposób niekontrolowany jako efekty pragnienia, albo też - pragnienie jest zawsze produkcja sieci powiązań. Jeden z czterech elementów modelu produkcji w kapitalizmie kognitywnym, czyli netware, powstaje w dużym stopniu nie na drodze inwestycji, lecz jako efekt społecznego życia oraz jako efekt pracy niematerialnej.

12 Nie wprowadzam do tekstu podstawowego rozróżnienia na negatywne i pozytywne czynniki zewnętrzne. Negatywne czynniki zewnętrzne są nierynkowymi szkodami wynikłymi z procesu produkcji, np. zanieczyszczenie środowiska naturalnego lub dezorganizacja życia wspólnoty, pozytywne zaś to czynniki dodatnio wpływające na proces produkcji lub też pozarynkowe pozytywne efekty procesu produkcji, np. wzrost szacunku pracowników dla siebie. W teorii kapitalizmu kognitywnego istotne są w zasadzie wyłącznie czynniki zewnętrzne pozytywnie wpływające na proces wytwarzania wartości dodatkowej.

13 W kontekście efektów zewnętrznych i kapitalizmu kognitywnego można również mówić o nowej roli innowacji i „przedsiębiorcy” opisywanych przez Schumpetera: o ile proces innowacji przebiegał według austriackiego ekonomisty niejako poza procesem produkcji, w wyniku połączenia przez innowacyjnego przedsiębiorcę dostępnych środków produkcji w nowy, nieznany wcześniej sposób, o tyle dzisiaj proces innowacji sytuuje się w samym centrum procesów ekonomicznych. 
Jak podkreśla to Moulier-Boutang, w kapitalizmie kognitywnym największą wartość wytwarzają ucieleśnione mózgi działające w sieciach komunikacji, a więc powiązanie hardware, software, netware i wetware. Istota analiz prowadzonych w ramach teorii kapitalizmu kognitywnego polega na badaniu zmiany struktury inwestycji w każdy z tych elementów i w ich powiązanie oraz wykształcania się - na bazie tej zmiany - nowego reżimu akumulacji kapitału:

1. Inwestycje w hardware kieruja się klasyczną logiką inwestycji w ekonomie skali, co dzisiaj przynosi już zyski stosunkowo małe w porównaniu z innymi modelami produkcji - toteż nic dziwnego, że produkcję tę przeniesiono w znacznym stopniu do krajów rozwijających się. Natomiast zarówno software, jak i netware oraz wetware wytwarzane sa na zasadzie obcej typowemu modelowi firmy.

2. Software może być wytwarzane przez swobodnie komunikujące się ze sobą podmioty, które nie potrzebują żadnych wspólnych środków produkcji, gdyż jedynym istotnym środkiem produkcji ich pracy jest odpowiednio skodyfikowany jezylk, paradygmatyczne „dobro wspólne"14.

3. Netware rozwija się dzisiaj, czy to w Internecie, czy w wielkich miastach, jako efekt życia społecznego i pragnienia komunikacji (na bazie infrastruktury powstającej najczęściej w ramach publicznych inwestycji).

4. Wetware pozostawała aż do kryzysu fordyzmu kwestią przynależną wyłącznie do obszaru reprodukcji społecznej, obecnie zaś sytuuje się w samym centrum transformacji rozwiniętych gospodarek - jest to stawka dokonującego się demontażu państwa dobrobytu i prywatyzacji wszystkich szczebli szkolnictwa, zwłaszcza szkolnictwa wyższego, oraz szerzenia się zadłużenia wśród młodych, wykształconych osób, finansujących długiem swoją edukację. A także przechwytywania przez sektor prywatny niegdyś rewolucyjnego hasła „uczenia się przez całe życie”. Znaczenie netware oraz wetware w modelu produkcji kapitalizmu kognitywnego zaciera istotne dla poprzedniego, fordystycznego reżimu ekonomicznego oddzielenie obszaru produkcji i reprodukcji społecznej, która to separacja stanowiła w fordyzmie fundament regulujący zarówno procesy produkcji, jak i akumulacji kapitału.

Specyfika kapitalizmu kognitywnego polega na tym, że software, netware oraz wetware funkcjonują zarówno jako efekty zewnętræne wobec procesów produkcji, jak i jako jego

14 Opis ekonomii produkcji w ramach open source zob. w Lerner i Triole 2002. Wspólny charakter podstawowego środka produkcji przy programowaniu wyjaśnia, dlaczego firmy produkujące oprogramowanie uciekają się do innych form wynagrodzenia niż płaca. Bill Gates stwierdził kiedyś, że gdyby nie wypłacanie części wynagrodzenia inżynierom oprogramowania w akcjach Microsoftu, zmiany personalne na stanowiskach następowałyby co sześć miesięcy, a nie co dwa lata. Jednym z istotnych aspektów odchodzenia programistów z firmy Microsoft była też ich niechęć wobec redukowania ich pracy do samej wartości pieniężnej (zob. Drucker 2002), co różni Microsoft, firmę o dość klasycznej organizacji i modelu zatrudnienia, od licznych firm powstałych lub przekształconych w okresie nowej ekonomii (jak chociażby Google czy Apple). Ciagła zmiana miejsca zatrudnienia przez informatyków w firmach informatycznych jest możliwa głównie dzięki temu, że w każdym miejscu pracy pracuja za pomoca tych samych środków produkeji. 
najważniejsze elementy składowe. O ile jeszcze bowiem software może być wliczany jako zwykły koszt (choć coraz więcej przedsiębiorstw korzysta z darmowego oprogramowania ${ }^{15}$ ), o tyle firmy nie muszą inwestować w wetware, korzystaja zaś masowo z netware, którego wytworzenie najczęściej nic ich nie kosztuje (oprócz może co najwyżej podatków).

W ramach reżimu akumulacji kapitalizmu kognitywnego mamy do czynienia z typowym uspołecznieniem kosztów oraz prywatyzacją zysków, przy czym transformacji uległy sposoby narzucania i kontroli obu tych operacji. Jedną z najbardziej charakterystycznych metod uspołeczniania kosztów produkcji jest angażowanie konsumenta w wytwarzanie produktu, co nie tylko przekłada się na zmianę struktury kosztów w zarządzaniu przedsiębiorstwami, ale ma także istotne znaczenie dla struktury zatrudnienia i udziału płac w gospodarce jako całości. Najwyraźniej widać ten proces w przypadku współwytwarzania wartości przez użytkowników portali społecznościowych. Według Tiziany Terranovy rozwój portali w rodzaju Friendster, Facebook, Flickr, Myspace, SecondLife, Blogger czy LinkedIn był strategia obraną przez rynek internetowy, poszukujący po roku 2000 nowych modeli biznesowych. W końcu jednym z najczęściej podawanych powodów niepowodzenia wielu firm internetowych w latach dziewięćdziesiątych była nieumiejętność zgromadzenia wystarczającej liczby użytkowników. Wszystkie portale powstały na gruncie Web 2.0 umożliwiały współtworzenie treści przez korzystających z serwisów użytkowników, co nie tylko zwiększało ich liczbę, ale też angażowało w wytwarzanie wartościowej treści. Interesujące jest to, że książka Benklera, pochwała wolnej i niezależnej produkcji w sieciach, wyszła w tym samym roku, w którym Web 2.0 została wybrana osobą roku magazynu TIME. Wydaje się, że Benkler nie zauważył momentu, w którym alternatywa dla kapitalizmu stała się jego nowym filarem ${ }^{16}$ :

Web 2.0 stanowi najlepszy możliwy model dla inwestorów, gdyż zbiera, inkorporuje i waloryzuje społeczną oraz technologiczną pracę użytkowników. Warunkiem kapitalistycznego procesu wytwarzania wartości dodatkowej w nowej ekonomii jest marginalizacja pracy najemnej oraz waloryzacja darmowej pracy użytkownika, a więc pracy nieopłacanej i nienadzorowanej, co nie znaczy, że niekontrolowanej (Terranova 2010, 156).

Wystartowanie Facebooka i LinkedIn na giełdach można zatem odczytać jako kolejny krok w długim marszu kapitału finansowego od początku lat osiemdziesiątych, którego celem było odejscie od inwestycji w beapośredni proces produkcji, a zamiast tego wytwarzanie aparatów przechwytu wartości wytwarzanej w obszarze całego spoteczeństwa. Matteo Pasquinelli mówi w tym kontekście również

15 Zob. http://www.revsys.com/writings/oss-in-business.html

16 Terranova złośliwie zauważa, że u niektórych apologetów wolnej produkcji na zasadzie open source, jak to ma miejsce według niej właśnie u Benklera, społeczna kooperacja w Internecie niepostrzeżenie zbliża się do niewidzialnej ręki rynku (Terranova 2010, 158). 
o wartości sieciowej (Pasquinelli 2009), która akumulowana jest przez algorytmy wyszukiwarek internetowych, przede wszystkim przez algorytm PageRank wykorzystywany przez Google. Podstawowa różnica między zasadą funkcjonowania PageRank a logiką wcześniejszych wyszukiwarek (np. Yahoo) polega na rejestrowaniu ruchu użytkowników w sieci: nadaje on określoną wartość stronie internetowej, opierając się na liczbie istniejących połączeń z innymi stronami internetowymi, jakości tych połączeń oraz ruchu użytkowników w sieci. Każde wejście na stronę, utworzenie połączenia z nią czy też wyszukanie danej strony w sieci zwiększa jej wartość, która może zostać łatwo przełożona na kapitał ekonomiczny dzięki platformie reklamowej Adwords, generującej przeważająca większość dochodów Google. Aparaty przechwytu wartości z obiegu informacji w sieci musza jednak obejmować odpowiednią skalę aktywności, by przechwytywana przez nie wartość mogła napędzać dalej proces akumulacji. Stosunek liczby użytkowników obejmowanych przez algorytmy wyszukiwarek oraz Web 2.0, jak i wytwarzanej przez nie wartości, do nakładów pracy i inwestycji potrzebnych do ich opracowania jest nieporównywalny z jakimikolwiek wcześniej znanymi mechanizmami wytwarzania wartości, co przekłada się oczywiście na olbrzymie stopy zysku i możliwości akumulowania kapitału nie w kapitale stałym, lecz w giełdowej wartości spółek. Z perspektywy ekonomii politycznej można postawić tezę o ciagłości tendencji do rosnacej stopy aysku w kapitalizmie kognitywnym, a więc tendencji odwrotnej do diagnozowanego przez Marksa, w odniesieniu do kapitalizmu przemysłowego, prawa malejącej stopy zysku (Marazzi 2008, 61).

Deregulację rynków finansowych, gromadzenie olbrzymich ilości kapitału przez prywatyzację oszczędności pracowników oraz rozkwit aparatów przechwytu wartości w sieci należy rozpatrywać jako elementy jednego reżimu akumulacji. Jak ujmuje to Terranova: „Z punktu widzenia nowych technologii (...) kapitał finansowy operuje jako główny zestaw (assemblage of assemblages), w którym wzajemnie przenikają się elementy techniczne, kulturowe, społeczne i psychologiczne" (Terranova 2010, 164) ${ }^{17}$. Operacje finansowe umożliwiaja połączenie w jeden globalny system ekonomiczny zgromadzonych na drodze prywatyzacji ubezpieczeń społecznych i emerytalnych oszczędności ${ }^{18}$ oraz inwestycji w rozwój aparatów przechwytu wartości wytwarzanej w sieciach komunikacji - zaangażowanie użytkowników stanowi przy tym element stabilizujący akumulację kapitału, gdyż zapewnia regularny rozrost

17 W tym samym kontekście Moulier-Boutang pisze o kapitale finansowym jako logice zarządzania efektami zewnętrznymi (Moulier-Boutang 2011, 143).

18 Możliwość inwestycji kapitału w sferę cyrkulacji i reprodukcji jest innym rozwiązaniem problemu, na który wskazywała już Róża Luksemburg, a mianowicie ciąłego poszukiwania przez kapitał nowych rynków zbytu. Kształtujący się już od dłuższego czasu model centrum-peryferie napędzany jest m.in. przez to, że kapitał w krajach rozwiniętych znalazł nowy obszar inwestycji, lokujący się poza bezpośrednimi procesami produkcji. W efekcie inwestycje w krajach rozwijających się sprowadziły się do offshoringu tych form produkcji, które w największym stopniu oparte były na niewykwalifikowanej sile roboczej (Urry 2014). 
portali oraz zwiększanie ilości gromadzonej informacji, która jest główną produkowaną przez te portale wartością.

Wysoka efektywność modelu produkcji kapitalizmu kognitywnego wynika z możliwości szybkiego i taniego powiązania w sieciach kooperacji użytkowników o różnych umiejętnościach. Proces produkcji ulega przez to rozproszeniu, a produktywny staje się praktycznie cały obszar społeczeństwa. Rozwój sieci komunikacji w obszarze całego społeczeństwa, a nie tylko szeroko rozumianego przemysłu sprawia, że model firmy charakterystyczny dla spółek w rodzaju Google jest coraz częściej przyjmowany także przez przedsiębiorstwa spoza sektora IT: „to nie natura produktu określa organizację (lub paradygmat) produkcji, lecz raczej związek między sferami produkcji i cyrkulacji, między produkcją i konsumpcją, kształtujący sposoby produkcji dóbr i usług” (Marazzi 2011, 55-56). Prowadzi to do pogłębiania się outsourcingu, prekaryzacji i generalnej dewaloryzacji siły roboczej ${ }^{19}$. Prywatyzacja zysków z aktywności netware i wetware nie wymaga inwestycji w ich rozwój, który pozostaje w dużym stopniu sprawą środków publicznych bądź też indywidualnych nakładów pracowników. Postępująca indywidualizacja kosztów reprodukcji i dostosowywania się do zmian na rynku pracy służy zaś za mechanizm kontroli siły roboczej (por. Standing 2014, 85-111). Co więcej, w przeciwieństwie do kapitalizmu opartego na inwestycjach w kapitał trwały w postaci maszyn fabrycznych, w kapitalizmie kognitywnym „płace realne nie są powiązane ze wzrostami wydajności, a w związku z tym nie ma sprawiedliwej kompensacji za prekarność zatrudnienia” (Fumagalli i Lucarelli 2014, 91).

Model produkcji kapitalizmu kognitywnego oparty na efektach zewnętrznych pokazuje raz jeszcze strukturalne i technologiczne powiązanie między transformacja kapitału, jego finansjeryzacją, oraz rozwojem technologii komunikacyjnych. Kapitał finansowy może pozostać „niezwiązany” dzięki temu, że nie jest inwestowany w środki produkcji w ramach bezpośrednich procesów produkcji, lecz w aparaty przechwytu wartości wytwarzanej $\mathrm{w}$ procesach cyrkulacji wiedzy $\mathrm{i}$ informacji oraz reprodukcji społecznej. Wysoka produktywność sieci komunikacji oraz napływ kapitału umożliwiają częściową stabilizację systemu, ale prowadzi to do braku inwestycji nakierowanych na tworzenie nowych miejsc pracy (Marazzi 2011, 53). Zamiast tego sugeruje się powrót do rzemieślniczej pracy w rodzaju wytwarzania aplikacji do App Store ${ }^{20}$. Problem polega jednak na tym, że te nowe formy

\footnotetext{
19 Szwedzki socjolog Göran Therborn podkreśla, że w „epoce informacji” „doszło do polaryzacji na rynku pracy $-z$ jednej strony wzrosła liczba dobrze płatnych zajęć wymagających wysokich kwalifikacji, z drugiej nisko płatnych i niepewnych miejsc pracy przy obsłudze członków dawnej klasy »kreatywnej«" (Therborn 2015, 143), przy czym szeregi tego drugiego rodzaju pracowników, do których należałoby zaliczyć rzesze sproletaryzowanego kognitariatu wykonującego proste, automatyczne operacje przed komputerami, zwiększyły się znacznie bardziej.

20 Warto przyjrzeć się raportowi „The Third Great Wave” opracowanemu przez magazyn The Economist (The Economist 2014), w którym obecną fazę transformacji kapitału analizuje się głównie pod kątem problemu technologicznego bezrobocia. Idea dochodu podstawowego, o której piszę dalej, zostaje krótko wspomniana
} 
przychodu nie zapewnią stabilizacji całego systemu. Jeśli jedną ze strategii wyjścia z obecnego kryzysu będzie akumulacja kapitału na drodze zwiększenia zysków z inwestycji w portale Web 2.0, co częściowo widać na przykładzie wzrostu cen akcji Facebooka i indeksu NASDAQ, to rozwiązanie to może prowadzić do kolejnego, być może jeszcze silniejszego kryzysu ekonomicznego. Reżim akumulacji kapitalizmu kognitywnego sam z siebie, bez interwencji politycznej, nie umożliwia bowiem wykształcenia się stabilizującego systemu regulacji stosunku między płacami, inwestycjami, konsumpcją i akumulacją kapitału finansowego.

Obserwowany rozwój gospodarczy polegający na przechodzeniu od inwestycji w bezpośredni proces produkcji do inwestycji w aparaty przechwytu wartości wytwarzanej w sferze cyrkulacji i reprodukcji stanowi potwierdzenie dwóch fundamentalnych tez teorii kapitalizmu kognitywnego. Po pierwsze, praca wytwarzająca wartość w kapitalizmie kognitywnym organizuje się niezależnie od zarządzania gospodarką przez przedsiębiorstwa. Ponieważ produkcja wiedzy i informacji zachodzi głównie w sieciach komunikacji, granice firm zacieraja się, przekształcając się w przedsiębiorstwa sieciowe. Prywatny charakter środków produkcji powoli zanika, zastępowany przez wielość prawnych i ekonomicznych aparatów gwarantujących prywatyzację zysków, głównie w formie narzucania patentów i intelektualnych praw własności (Vercellone 2008, 7). Postępuje demontaż państwa dobrobytu (które stanowiło czynnik ukonstytuowania się kapitalizmu kognitywnego), przez co zwiększa się prekaryzacja siły roboczej i zmniejsza się jej opór przed wchodzeniem w stosunek pracy najemnej (Vercellone 2008, 10), który to stosunek w dobie kapitalizmu kognitywnego nie jest niezbedny, by usyskać dostęp do środków produkecji, jest niemniej wciąż w dużym stopniu nię̧bedny, by uzyskać dostęp do środków utraymania. Oznacza to, że zapewnienie środków utrzymania wystarcza, by umożliwić produktywna pracę. Instytucje państwa dobrobytu w kapitalizmie kognitywnym funkcjonują zatem jako caynnniki produkcji (Vercellone 2014), które umożliwiają pracę w sieciach komunikacji poza strukturami przedsiębiorstw (a więc poza typowymi stosunkami pracy najemnej). Funkcja państwa w modelu kapitalizmu kognitywnego powinna zostać ujęta zarówno jako źródło inwestycji sektora publicznego, jak i jako czynnik rozwoju efektów zewnętrznych (przy czym obie te funkcje działają także na korzyść biznesu, prywatyzującego efekty produkcji w sieciach kooperacji).

\footnotetext{
i odrzucona jako odbierająca godność płynącą z wykonywanej pracy, natomiast nowe formy pracy, które maja zastapić zatrudnienie $\mathrm{w}$ wysoko zautomatyzowanym przemyśle, rozważa się w kontekście samodzielnie prowadzonych biznesów sieciowych oraz sprekaryzowanych i do tego nisko płatnych zadań związanych z obróbką informacji. Autorzy raportu starają się na siłę opracować ideał polityki gospodarczej będącej odpowiedzia na kolejną „wielką transformację”, natomiast ich analizy jasno pokazuja, że jedną z możliwych strategii stabilizacji reżimu akumulacji $\mathrm{w}$ ramach dalszego technicznego rozwoju procesów produkcji jest zwiększenie bezrobocia i „uelastycznienie” stosunków pracy. Rola rynków finansowych zostaje całkowicie pominięta. Raport The Economist można potraktować jako przykład wniosków wyciaganych na bazie teorii ekonomicznej wychodzącej od technologicznego determinizmu, a nie stosunków społecznych.
} 
Po drugie, w reżimie akumulacji kapitalizmu kognitywnego można mówić o stawaniu się zysku na powrót rentą (Vercellone 2008). W klasycznym ujęciu ekonomicznym inwestycja w bezpośredni proces produkcji ma na celu wygenerowanie przychodu większego od poniesionych kosztów inwestycyjnych. Ponieważ w kapitalizmie kognitywnym najbardziej rentowne inwestycje nie są już dokonywane w płace i środki pracy, lecz w aparaty przechwytu wartości wytwarzanej $\mathrm{w}$ sieciach wymiany wiedzy i informacji oraz $\mathrm{w}$ ramach reprodukcji społecznej, powstaje olbrzymia ilość wartości dodatkowej nieinwestowanej z powrotem w bezpośredni proces produkcji. Prowadzi to nie tylko do zmniejszania udziału płac w dochodzie krajowym (Husson 2011, 17), lecz również do dominacji reżimu akumulacji charakterystycznego dla kapitału kognitywnego i finansowego nad innymi, bardziej stabilnymi reżimami akumulacji. Renta, podstawowy mechanizm czerpania zysku z kapitału finansowego, staje się dzisiaj dominującą logiką stosunków społecznych, czy to w postaci nieustannego poszukiwania zysków na drodze renty przez kapitał finansowy, czy w stawaniu się rentą części wynagrodzeń (w postaci np. opcji na akcje) (Marazzi 2011, 61), czy też w postaci czerpania zysków z masowego zadłużania się populacji w krajach rozwiniętych i rozwijających się. Uderzające jest to, że trwający obecnie kryzys finansowy nie doprowadził do usunięcia tych mechanizmów finansowych.

\section{Intelekt powszechny i organiczny skład kapitału w kapitalizmie kognitywnym}

W sformalizowanym modelu kapitalizmu kognitywnego czynnikami zwiększającymi produktywność są efekty zewnętrzne oraz efekty inwestycji w ekonomie uczenia się. Warunkiem ich efektywności nie jest już obecnie technologia zakumulowana w materialnych maszynach będących, jako środki produkcji, własnością kapitalistów, lecz umiejętności zawiązywania współpracy i komunikowania się. Kapitalizm kognitywny jawi się w tym kontekście jako nowy etap w historycznym procesie podziału pracy. W wymiarze globalnym przerzucenie procesów produkcji hardware (a także w dużym wymiarze software) do krajów rozwijających się oznacza ukonstytuowanie się nowej relacji centrum-peryferie opartej na zróżnicowanym poziomie organicznego składu kapitału: w krajach rozwijających się i peryferyjnych niski organiczny skład kapitału umożliwia ekstrakcję wartości dodatkowej z pracy przemysłowej (lub pracy zorganizowanej na wzór przemysłowy np. w indyjskich call centers czy fabrykach produktów i usług IT), podczas gdy w krajach centrum największą marżę zysku przynosi przechwytywanie wartości wytwarzanej przez pracę kognitywną w sieciach 
kooperacji ${ }^{21}$. Jednocześnie zmienia się też podział pracy w ramach bezpośrednich procesów wytwarzania wiedzy i informacji.

Carlo Vercellone podkreśla, że z perspektywy uformowania się kapitalizmu kognitywnego można podsumować poprzednie fazy rozwoju kapitalizmu (rozwój manufaktury i rozwój wielkiego przemysłu) jako procesy dążące do wywłaszczenia wiedzy pracujących podmiotów i przetransponowania jej w kapitał trwały (Vercellone 2007, 16-17). Wyzysk polegał zatem nie tylko na wyzysku pracy, ale także na oddzieleniu robotnika od wiedzy niezbędnej do zrozumienia całego procesu produkcji i przez to też zależnego od dostępu do środków produkcji będących własnością kogoś innego (Bowring 2004). Kapitalistyczny podział pracy w tym sensie był zawsze kognitywnym podriałem pracy, a relacje władzy w społeczeństwach kapitalistycznych dotyczyły dystrybucji wiedzy determinowanej przez hegemoniczny model produkcji. W kapitalizmie kognitywnym podział pracy w ramach procesu wytwarzania wiedzy i informacji nie dokonuje się już w oparciu o technologiczny rozwój hardware, lecz na bazie zarządzania kooperacją software, netware oraz wetware. Mówiąc inaczej, wiedza ucieleśniona i charakterystyczne dla niej modele organizacji zyskuja przewagę nad organizacją narzucana przez kapitał trwały oraz organizację korporacyjną (Vercellone 2007, 32). Proces ten postoperaistyczni teoretycy opisują za pomocą reinterpretacji Marksowskiego pojęcia „intelektu powszechnego" (Virno 1992; Vercellone 2007; zob. Szadkowski 2013), pojawiającego się we fragmencie Zarysu krytyki ekonomii politycznej. We fragmencie tym Marks kreśli perspektywę dalszego rozwoju kapitalizmu (Marks 1986, 564-574). Twierdzi, że z czasem aplikowanie nauki do procesu produkcji na drodze transpozycji społecznie wytworzonej wiedzy do kapitału trwałego (maszyn) doprowadzi do kryzysu kapitalistycznych metod pomiaru wartości pracy opartych na mierzeniu indywidualnego czasu pracy. Zakumulowana wiedza stanie się bowiem bezpośrednią siłą wytwórczą, a jej wytwarzanie istotniejsze od indywidualnej, manualnej pracy robotnika. Krystian Szadkowski podkreśla, że teza ta jest zgodna z późniejszym Marksowskim twierdzeniem o spadku stopy zysku wraz ze wzrostem organicznego składu kapitału (Szadkowski 2013, 75). Wzrost organicznego składu kapitału w sektorze przemysłowym prowadzi do poszukiwania nowych obszarów społecznej produkcji, których objęcie relacja pracy najemnej przywróci wysoki stopień wytwarzania wartości dodatkowej. Przypomnijmy, że moment ten Christian Marazzi sytuuje na przełomie lat sześćdziesiątych i siedemdziesiątych, kiedy fordystyczny reżim produkcji wszedł w okres kryzysu. Wyjście z kryzysu kapitalizmu przemysłowego polegało na inwestowaniu społecznych oszczędności w rozwój nowych technologii. Inwestycje te mogły jednak przywrócić wysoką

21 Dotyczy to nie tylko Internetu, lecz również rynku sztuki oraz różnego rodzaju dóbr luksusowych, na których również dochodzi do akumulacji przez konkretne marki lub osoby (sławnych artystów) wartości sieciowej, wytwarzanej przez opiniotwórcze media, blogerów, targi, wystawy itd. (Ratajczak 2014). 
rentowność, gdyż intelekt powszechny, a więc bezpośrednio produktywna wiedza, przyjął postać nie kapitału zakumulowanego w maszynach, lecz rozproszonej inteligencji - żywej wiedży.

Jednym z najważniejszych celów teorii kapitalizmu kognitywnego jest opisanie tej produktywności rozproszonej inteligencji w kategoriach organicznego składu kapitału ${ }^{22}$. O ile bowiem w kapitalizmie kognitywnym dalej mamy do czynienia ze stosunkami kapitalistycznymi, a więc z opozycją między kapitałem stałym i kapitałem zmiennym, o tyle podstawowe dla kapitalizmu kognitywnego powiąania hardware, software, netware i wetware charakteryzujące pracę kognitywną oznacza zmianę natury zarówno kapitału stałego, jak i kapitału zmiennego.

Jednoznaczna diagnoza, czym jest kapitał stały i zmienny w dobie kapitalizmu kognitywnego, jest trudna. Można to uznać za nieadekwatność Marksowskiej ekonomii politycznej do analizy współczesnej gospodarki opartej na wiedzy. Można też stwierdzić, że pojęcia kapitału stałego i zmiennego, podobnie zresztą jak żywej i martwej pracy, mają charakter funkcyjny i opisuja raczej relacje ekonomiczne, a nie stałe elementy rzeczywistości. W tym sensie praca ludzka nie jest tożsama z żywa praca, płaca nie jest tożsama $z$ kapitałem zmiennym, a kapitał stały nie jest tożsamy z maszynami fabrycznymi. Kryzys fordyzmu doprowadził do tak fundamentalnego przeobrażenia rzeczywistości społecznej, że oderwał kategorie ekonomiczne od ich, zdawałoby się, „naturalnych” desygnatów. Każda poważna analiza ekonomiczna musi dzisiaj wyjść od tego, że nowy etap kapitalistycznego rozwoju wymusza zmianę rozumienia pojęć, które służyły do opisu kapitalistycznej rzeczywistości. Nie oznacza to od razu zmiany samych teoretycznych podstaw krytyki, a więc relacji wiążących wykorzystywane w krytyce pojęcia, lecz przede wszystkim desygnatów tych pojęć ${ }^{23}$.

W próbie sformułowania teorii organicznego składu kapitału w kapitalizmie kognitywnym należałoby wyjść od spostrzeżenia Roberta Boyera:

Jeśli chodziłoby o sformułowanie prognozy, który model (produkcji - przyp. MR) wykrystalizuje się w nadchodzących dekadach, to trzeba by najprawdopodobniej mówić

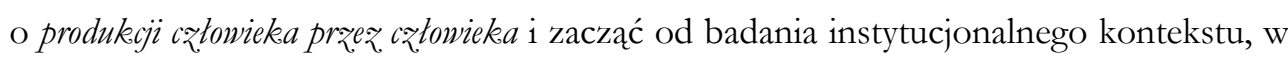
którym mogłoby dojść do powstania tego modelu (Boyer 2002, 192).

Zgodnie z diagnozą Boyera, obok Aglietty jednego z głównych teoretyków podejścia regulacjonistycznego, rozwijający się model produkcji, który zyskuje hegemoniczną pozycję

22 Dochodzimy tutaj ponownie do różnicy perspektywy między teorią kapitalizmu kognitywnego i teorią pracy biopolitycznej. O ile ta pierwsza skupia się przede wszystkim na transformacji reżimu akumulacji, o tyle tę drugą interesuja przede wszystkim nowe postacie pracy i produkcji i zawarty w nich potencjał polityczny. Dlatego też w ramach teorii pracy biopolitycznej badać należy nie tyle przekształcenia organicznego składu kapitału, lecz polityczny i techniczny skład żywej pracy (Hardt i Negri 2012, 231).

23 Na tym w przybliżeniu polega stosowana przez Marksa metoda „abstrakcji określonej” (Vinci 2014). 
w ramach obecnej transformacji społeczeństw rozwiniętych, będzie polegał na wytwarzaniu różnego rodzaju dyspozycji u podmiotów w ramach ich kooperacji z innymi podmiotami (zob. też Virno 2014). Wykorzystując perspektywę wprowadzoną przez Boyera, Christian Marazzi proponuje przeformułowanie kategorii kapitału stałego i zmiennego:

Ciało siły roboczej funkcjonuje (...) nie tylko jako nośnik siły roboczej, lecz również jako nośnik funkcji kapitału trwałego, środków produkcji, jako miejsce sedymentacji skodyfikowanej wiedzy, historycznie nagromadzonych umiejętności, produktywnych gramatyk, doświadczeń, krótko mówiąc: przeszłej żywej pracy (Marazzi 2014a, 44)24.

Organiczny skład kapitału przyjmuje zatem postać stosunku wykształtowanych umiejętności podmiotu do każdorazowego ich wykorzystania ${ }^{25}$. Gwałtowny rozwój dynamicznych ekonomii uczenia się można zatem uznać za rozwój sektora produkcji środków produkcji, gdyż największą wartość dodatkową wytwarza dzisiaj praca podmiotów wyposażonych $\mathrm{w}$ odpowiednie, poszukiwane przez kapitał zdolności, zdobywane w wyniku określonego treningu, edukacji i szkoleń. Wyjaśnia to również przynajmniej niektóre ze strukturalnych zmian, które zaszły w ostatnich latach w organizacji przedsiębiorstw, takich jak outsourcing oraz uelastycznienie zatrudnienia. André Gorz podkreślał, że eksternalizacja produkcji, przerzucanie kapitału materialnego oraz zadań produkcyjnych do podwykonawców (niezależnych wytwórców lub firmy-córki) oznacza nowy podział pracy nie tylko w postaci redukcji zatrudnienia do wąskiego rdzenia stałych pracowników, ale również przez nowe możliwości intensyfikacji wyzysku - firma-matka pozostaje w stosunku do swoich partnerów w relacji suwerennej władzy, mogąc w każdym momencie rozpocząć renegocjacje kontraktu i wymuszać zwiększenie produktywności (Gorz 2010, 58). Rdzeniem i istotą firmy przestaje być już własność materialnych środków produkcji, a staje się w coraz większym stopniu organizacja pracy i własność dóbr „niematerialnych” (prawa własności, patenty, logo, bazy danych, aktywa finansowe itp.).

Separacja robotników od kapitału stałego uległa (przynajmniej częściowemu) zniesieniu; na miejscu separacji od środków produkcji ukształtowała się prosta separacja od środków utrzymania - choć środki produkcji maja dzisiaj coraz częściej postać dobra wspólnego i ucieleśnionych dyspozycji, reprodukcja społeczna wciąż zapośredniczona jest

24 Idea traktowania typowo „ludzkich” umiejętności zgodnie z Marksowskimi kategoriami ekonomicznymi ma we Włoszech długą tradycję, zwłaszcza w obszarze lingwistyki i filozofii języka, która przyczyniła się znacząco do rozwinięcia teorii pracy niematerialnej i kapitalizmu kognitywnego właśnie tam. Zob. zwłaszcza książkę Ferruccio Rossi-Landi z roku 1968 Jezy/k jako praca i jako rynek: „,nosimy w sobie całe doświadczenie językowe gatunku, tak że każde dziecko, gdy tylko zaczyna mówić, używa nadzwyczaj skomplikowanych środków i narzędzi. Tak samo sprawy się mają z produkcją materialną” (Rossi-Landi 1968, 240).

25 Dokładnie takie samo ujęcie stosunku kapitału zmiennego do kapitału stałego w pracy artysty możemy znaleźć w teoretycznych tekstach Diedericha Diederichsena (Diederichsen 2010; zob. Ratajczak 2014). 
w pieniądzu wypłacanym za wykonywanie pracy produkcyjnej, a więc pracy przynoszącej zysk i reprodukującej kapitał. Tę jednoczesną autonomizacje pracy przy utrzymywaniu się utowarowienia reprodukcji społecznej podkreśla ruch Copyfarleft (Kleiner 2007; zob. Vieira i De Filippi 2014). Krytykuje on rozpowszechnienie się wolnych licencji (od GPL po różne wersje licencji CC) nie z pozycji ochrony praw własności, lecz bronienia interesów wytwórców, którym wolne licencje nie gwarantują możliwości zarabiania na efektach własnej pracy. Licencja Copyfarleft zaproponowana przez Kleinera rozróżnia między użytkiem niekomercyjnym i komercyjnym i nakłada odpowiednie opłaty na ten drugi, gwarantując równą dystrybucję uzyskanych przychodów między wszystkich wytwórców. Interwencja Kleinera wprowadza płacę za kognitywna pracę w postaci pewnego rodzaju renty dla prekarnych pracowników „przemysłów kreatywnych”, którzy pozbawieni dzisiaj stałego zatrudnienia, stają się często mimowolnymi ofiarami technologicznego rozwoju. Pokazuje także, że cyfrowy obieg wiedzy nie jest sprawą wyłącznie techniczną i legalną, lecz dotyczy również dystrybucji i apriopriacji wartości wymiennej.

Zaproponowane przez Marazziego ujęcie organicznego składu kapitału umożliwia nie tylko formułowanie nowej filozofii politycznej, kreślącej horyzont aktywizmu i oddolnej organizacji w dobie hegemonii pracy kognitywnej; tłumaczy również funkcjonowanie reżimu akumulacji kapitalizmu kognitywnego. Niezależnie od wprowadzenia nowych postaci wynagrodzenia w rodzaju opcji na akcje czy renty za udzielanie licencji, płace obejmują wciąż zasadniczo jedynie wykonana pracę; jednocześnie coraz mniejszą część inwestycji kapitału obejmują inwestycje w kapitał trwały, gdyź środki produkcji są powszechnie dostępne lub też wchodzą w zakres reprodukcji siły roboczej - pozostałe środki w rodzaju infrastruktury, samochodów czy biur najczęściej się wynajmuje (Marazzi 2014a, 36). Redukcja kosztów po stronie firm nie oznaczała jednak zwiększenia płac, lecz przesunięcie kosztów inwestycyjnych oraz amortyzacyjnych na stronę żywej pracy, której uczestnictwo w procesie społecznej produkcji nie kończy się zresztą w momencie zakończenia konkretnego zadania i czasu, za który jej zapłacono - jej praca pokrywa się z uczestnictwem w życiu społecznym i jego reprodukcja, gdyż wtedy wytwarza większą część swojego (a zarazem społecznego) kapitału stałego.

Ujęcie to rozszerzył Matteo Pasquinelli, który do organicznego składu kapitału zaliczył nie tylko wetware oraz netware, lecz również software. Odróżnił bowiem od pracy kognitywnej prace informacyjna, która jest możliwa dzięki masowemu rozpowszechnieniu się maszyn obliczeniowych (komputerów) (Pasquinelli 2011, 150). „Intelekt powszechny” dla Pasquinelliego to nie tyko wiedza zakumulowana w żywych ciałach siły roboczej (jak ujmują to Marazzi, Virno i Vercellone), lecz również kod cyfrowy, który może zostać „,wykonany” przez maszyny obliczeniowe. O ile zatem Marazzi i Vercellone ujmowali za Virnem intelekt powszechny przede wszystkim z perspektywy logiki wypowiedzi i kreatywnej aktywności 
językowej (Virno 2003), o tyle dla Pasquinelliego intelekt powszechny mówi jednocześnie językiem naturalnym oraz językiem skodyfikowanym, który należy ujmować jako algorytm. Algorytmy nie są niezależnymi siłami, autonomicznymi podmiotami, lecz należy je rozpatrywać jako kapitał stały, który generuje wartość, będąc ,aktualizowanym” przez żywą pracę na drodze każdorazowego użycia określonego oprogramowania. Wzór c/v w kapitalizmie kognitywnym przybierałby zatem postać:

(algorytmy kierujące maszynami obliczeniowymi + wykształcone umiejętności żywej pracy)

(każdorazowa aktualizacja maszyn obliczeniowych + każdorazowa aktualizacja wykształconych umiejętności)

Takie sformułowanie organicznego składu kapitału tłumaczy centralność efektów zewnętrznych w reżimie akumulacji kapitalizmu kognitywnego. Kapitał w równym stopniu wynajmuje dziś (zamiast inwestować w jego rozwój) kapitał trwały („kapitał materialny”), jak i kapitał „stały”. O ile jednak cena kapitału materialnego kształtowana jest przez relacje rynkowe, o tyle koszt kapitału „stałego” jest kwestią czysto polityczną, determinowaną przez konkretne regulacje prawno-polityczne, konwencje kulturowe bądź też aktualny opór i organizacje pracowników. Ile należy zapłacić za daną umiejętność? Jaką wartość ma dany algorytm? Ile darmowej pracy (użytkowników) niezbędne jest do zebrania odpowiedniej wartości sieciowej? Jak określić relacje między darmowa produkcja człtowieka przę człowieka a ta samą produkcją, ale już opłacaną? W którym momencie kończy się praca? Jak w ogóle odróżniać kapitał „stały” od „zmiennego”?

\section{Funkcje kapitału finansowego w reżimie akumulacji kapitalizmu kognitywnego}

W tym momencie należy wrócić do tezy o kapitale finansowym jako instrumencie zarządzania efektami zewnętrznymi i podsumować wszystkie dotychczasowe ustalenia. Właściwym przedmiotem inwestycji w kapitalizmie kognitywnym nie są inwestycje w środki pracy, lecz w środki akumulacji wartości. Przyjrzyjmy się różnicy między boomem „nowej ekonomii” w latach dziewięćdziesiątych a obecnym rozwojem kapitalizmu kognitywnego, którą można wyrazić za pomoca tezy Pasquinelliego o narodzinach „społeczeństwa metadanych” (Pasquinelli 2011, 153). Większość spółek, które zbankrutowały podczas krachu dotcomów, świadczyła ten sam rodzaj usług, co tradycyjne przedsiębiorstwa, tyle że robiły to przez Internet. W tym sensie polegały na typowej pracy organizacyjnej, logistycznej i usługowej. Warunkiem sukcesu takich firm jak Amazon, Ebay, a także LinkedIn, Facebook czy w końcu Google jest inwestowanie w kapitał stały w postaci algorytmów, które są ,,aktualizowane” (czyli produkują wartość) dzięki pracy użytkowników wytwarzających powiązania między stronami i produktami, akumulując „wartość sieciową". Firmy te zainwestowały nie tyle w liczne nowe, lepsze stanowiska pracy, 
lecz w algorytmy zbierania informacji o informacji, które umożliwiły im efektywne i praktycznie darmowe akumulowanie aktywności użytkowników w postaci metadanych. Algorytmiczny kapitał stały sprowadza się zatem do odpowiedniego mechanizmu akumulowania uwagi, pragnień i spostrzeżeń podmiotów komunikujących się w sieci. Inwestycje w kapitał materialny oraz w stabilność zatrudnienia zostają zminimalizowane. Akumulacja kapitału nie przebiega już $\mathrm{w}$ postaci akumulowania wartości w kapitale stałym, lecz w wartości giełdowej przedsiębiorstwa, w postaci kapitału finansowego. Jest to pierwsza funkcja kapitału finansowego jako regulatora akumulacji w kapitalizmie kognitywnym: zapewniać możliwość akumulacji poza inwestycjami w kapitał trwały (stały).

Kolejna funkcja kapitału finansowego polega na regulowaniu wydatków przedsiębiorstw. Coraz szerzej stosowana w spółkach giełdowych zasada shareholder value (Aglietta i Rebérioux 2004) nakazuje kierować się w zarządzaniu budżetem przedsiębiorstwa przede wszystkim zyskami akcjonariuszy. Ich zyski z inwestycji mają zatem priorytet przed płacami pracowników. Zasada ta dyscyplinuje kierownictwo firmy, pogłębiając naciski na prekaryzację i outsourcing zatrudnienia, oraz redystrybuuje ryzyko ekonomiczne z akcjonariuszy i zarządu na pracowników (Marazzi 2014a, 55), uzależniając ich dochody lub stabilność zatrudnienia od aktualnej kondycji finansowej firmy i sytuacji na rynku. Brak strukturalnej konieczności inwestycji w kapitał stały (oraz „trwały”) pogłębia tylko ten brak regulacji między zyskami, inwestycjami i płacami w kapitalizmie kognitywnym. Przy coraz bardziej „niematerialnym” charakterze przedsiębiorstw sieciowych to zasada shareholder value służy za mechanizm regulujący relacje władzy między właścicielami i pracownikami.

Po trzecie, obecna, neoliberalna ekspansja kapitału finansowego napędza wspominana już wcześniej prywatyzację struktur reprodukcji społecznej: od ubezpieczeń przez fundusze emerytalne po struktury edukacyjne. Ten „socjalizm kapitału” (Marazzi 2014b) nie tylko umożliwił uwolnienie olbrzymiej ilości zakumulowanej wartości, co stanowiło warunek restrukturyzacji całego procesu akumulacji kapitału w latach osiemdziesiątych, lecz również doprowadził do prywatyzacji procesu wytwarzania kapitału stałego (w sensie zakumulowanych umiejętności siły roboczej). Gwałtowne zadłużenie się populacji krajów rozwiniętych (Lazzarato 2012) spowodowane było nie tylko redukcja płac i inflacją cen nieruchomości od lat osiemdziesiątych w górę, lecz również jednoczesną prywatyzacją struktur reprodukcji i przerzuceniem kosztów tejże reprodukcji na pracowników. W tym sensie można mówić o hegemonii reżimu akumulacji kapitalizmu kognitywnego: powiązanie rozwoju gospodarki opartej na wiedzy z inwestycjami kapitału finansowego (a więc uformowanie się kapitalizmu kognitywnego jako finansowej gospodarki produk.ji) wykształciło reżim akumulacji, który operuje przez wytwarzanie wartości dodatkowej z pracy nieopłacanej („przechwytywaniu” autonomicznie wytworzonej wartości), redukcję inwestycji w kapitał stały i trwały oraz 
finansowanie długiem sprywatyzowanych kosztów reprodukcji społecznej (czyli „inwestycji” w kapitał stały) przez siłę robocza.

Wszystkie trzy funkcje kapitału finansowego stanowią czynniki determinujące ukształtowanie się kapitalizmu kognitywnego jako gospodarki napędzanej przez finanse. Warto podkreślić, że połączenie tych funkcji, wytworzenie prawdziwie „niematerialnego” reżimu akumulacji kapitalizmu kognitywnego (choć mającego jak najbardziej materialne konsekwencje w postaci wywłaszczeń domów, bezrobocia, ograniczonej konsumpcji i zubożenia znacznej części populacji) zasadza się na tym samym kapitale stałym, który tworzy współczesną postać intelektu powszechnego. Obok algorytmów przekładających informację na inną informację funkcjonują algorytmy akumulujące informację o informacji; a obok umiejętności produkcji człowieka przez człowieka wykształcane są umiejętności kontroli człowieka przez niego samego. Akumulacja wartości sieciowej przez aparaty jej przechwytu byłaby niemożliwa, gdyby kapitałem stałym w kapitalizmie kognitywnym nie były również algorytmy; tak samo prekaryzacja zatrudnienia oraz wytwarzanie wartości w obszarze reprodukcji społecznej nie byłyby możliwe, gdyby kapitału stałego nie tworzyły ucieleśniona wiedza i umiejętności ideologia „kapitału ludzkiego" nie doprowadziłaby inaczej do powstania wielości „przedsiębiorców siebie”, którzy rezygnują ze stałego zatrudnienia w imię niezależnego i autonomicznego kształtowania własnych ,ja” (Lorey 2014). Tym samym koncepcja organicznego składu kapitału w kapitalizmie kognitywnym łączy dwa obszary dalszych badań: ekonomię polityczną maszyny Turinga oraz biopolitykę „socjalizmu kapitału finansowego”.

\section{Uwaga o dochodzie podstawowym}

Większość badaczy kapitalizmu kognitywnego twierdzi, że interwencja politycznoekonomiczną, która mogłaby doprowadzić do większej stabilizacji tego reżimu akumulacji, byłoby wprowadzenie powszechnego, gwarantowanego dochodu podstawowego. Specyfika pracy kognitywnej, której podstawowym rzadkim zasobem jest czas i która wymaga też odpowiednich warunków psychospołecznego rozwoju ucieleśnionych mózgów, powoduje, że zagwarantowanie podmiotom tego rodzaju pracy podstawowego dochodu przyczyniłoby się do generowania i dyfuzji wiedzy, a więc, zgodnie z makroekonomicznym modelem kapitalizmu kognitywnego, zwiększałby wydajność całego systemu. Dochód podstawowy służyłby także za swego rodzaju „amortyzację” kapitału stałego, a więc kosztów rozwijania umiejętności przez pracowników (Marazzi 2014a). Dzięki wysokiej kumulatywności nowych technologii cyfrowych inwestycje w ten kapitał stały przekładałyby się wprost na efektywność innego rodzaju inwestycji: dochód podstawowy zwiększałby dynamikę procesów 
uczenia się i dyfuzji wiedzy, co wpływałoby na produktywność, a w efekcie inwestycje miałyby większe przełożenie na wzrost gospodarczy (Fumagalli i Lucarelli 2014, 95). Maciej Szlinder twierdzi, że możliwość zwiększenia wzrostu w kapitalizmie kognitywnym dzięki wprowadzeniu dochodu podstawowego wskazuje na zachodzenie w kapitalizmie kognitywnym związków „między zmiennymi makroekonomicznymi, które byłyby właściwe dla pewnej formy ekonomii efektywnego popytu” (Szlinder 2014, 132), co miałoby świadczyć o dużo większym podobieństwie wcześniejszych modeli gospodarczych do reżimu akumulacji kapitalizmu kognitywnego. Dzięki temu efekty mnożnikowe w wyniku wprowadzenia dochodu podstawowego doprowadziłyby do zwiększenia wpływów do budżetu państwa, które mogłyby z kolei sfinansować wypłacanie dochodu podstawowego. Co więcej, wprowadzenie dochodu podstawowego w kapitalizmie kognitywnym było krokiem w kierunku transformacji tej gospodarki w stronę społeczeństwa postkapitalistycznego. Podkreślanie różnicy między kapitalizmem kognitywnym jako finansowa gospodarka produkcji a poprzednimi systemami gospodarczymi ma tutaj na celu nie tyle dyskutowanie z argumentacją Szlindera o możliwości finansowania dochodu podstawowego i wyjścia poza kapitalizm, lecz pokazanie, że wprowadzenie gwarantowanego świadczenia pieniężnego byłoby nie tylko gestem sprawiedliwości społecznej i interwencja zwiększającą wydajność gospodarki, lecz również aktem przeciwstawienie sie władsy kapitalu finansowego. Wprowadzenie powszechnego dochodu podstawowego, który zastępowałby większość innych świadczeń społecznych, 1. przeciwstawiłoby się w znacznym stopniu prywatyzacji ubezpieczeń społecznych i funduszy emerytalnych, 2. uniezależniłoby częściowo pracowników od sytuacji finansowych prywatnych firm, co mogłoby w perspektywie doprowadzić do rozluźnienia i zniesienia zasady shareholder value i ukształtowania się innej dystrybucji ryzyka, oraz 3. dzięki finansowaniu go z odpowiednio skonstruowanego systemu podatkowego ograniczyłoby częściowo wartość akumulowaną w postaci kapitału finansowego na giełdach. Mówiąc inaczej, dochód podstawowy jako warunek transformacji kapitalizmu miałby nie tylko funkcje generowania większego wzrostu dzięki zwiększaniu produktywności inwestycji, a przez to wpływów do budżetu (przy wprowadzeniu odpowiedniego opodatkowania), lecz przede wszystkim znacznego oswobodzenia pracy kognitywnej i produkcji wiedzy od kapitału finansowego, odpowiedzialnego za utrzymywanie się kapitalistycznych stosunków społecznych w modelu produkcji, który nie jest oparty na własności środków produkcji. 


\section{Podsumowanie - sprzeczności kapitalizmu kognitywnego}

Kapitalizm kognitywny był w tym tekście rozpatrywany jako reżim akumulacji wartości wytwarzanej przez pracę kognitywną i produkcję wiedzy. Wykształcił się on w efekcie kryzysu fordyzmu, stanowiąc reakcję na spadającą stopę zysku w kapitalizmie przemysłowym. Nie jest to jedyny funkcjonujący obecnie reżim akumulacji, niemniej dwa czynniki powoduja, że kapitalizm kognitywny można rozpatrywać jako hegemoniczny model akumulacji kapitału. Po pierwsze, zastosowanie techniki w przemyśle oraz rozwój nowych technologii komunikacji uczyniły wiedzę i informację najistotniejszymi czynnikami produkcji i główną dźwignią innowacji. Po drugie, opisana w tekście zależność między akumulacją wartości w kapitalizmie kognitywnym a finansjeryzacja gospodarki umożliwiła akumulację olbrzymiej ilości wartości przez firmy działające w sektorze informatycznym i high-tech. Oba te czynniki sprawiaja, że reżim akumulacji kapitalizmu kognitywnego - napędzanie rozwoju inwestycjami finansowymi, rola efektów zewnętrznych, prekaryzacja zatrudnienia, przekształcenie organicznego składu kapitału itd. - determinuje także inne obszary gospodarcze. Prowadzi to do powstania różnego rodzaju sprzeczności.

Jedną z największych sprzeczności kapitalizmu kognitywnego jest mistyfikacja materialnego charakteru pracy kognitywnej. Po pierwsze, choć hardware nie stanowi istotnego elementu pracy kognitywnej pod kątem wartości ekonomicznej (nie składa się na kapitał stały w kapitalizmie kognitywnym), jest on jej niezbędnym elementem, wytwarzanym w warunkach ciężkiej, słabo opłacanej pracy fabrycznej, której offshoring do krajów rozwijających się determinuje globalny kognitywny podział pracy. Po drugie, produkcja hardware wymaga często olbrzymich nakładów surowców naturalnych, co mocno komplikuje mówienie o „niematerialnym” charakterze reżimu akumulacji kapitalizmu kognitywnego. Po trzecie w końcu, „produkcja człowieka przez człowieka”, a więc paradygmat pracy kognitywnej, jest w pierwszym rzędzie pracą afektywną, opiekuńczą i wychowawczą. Prymat pracy kognitywnej, za który słusznie były krytykowane pierwsze koncepcje pracy niematerialnej, nie jest tylko kwestia ideologicznego odmawiania pracy reprodukcyjnej i afektywnej statusu pracy produkcyjnej. Ten stan rzeczy podtrzymywany jest przede wszystkim przez zależność wzrostu w kapitalizmie kognitywnym od inwestycji kapitału finansowego, który największe zyski czerpie z przechwytywania wartości wytworzonej przez pracę kognitywną. Produkcyjny okazuje sie ten kapitat stały, którego ,aktualizacja” jest mo:̇liwa do skodyfikowania i akumulacji. Praca afektywna czy opiekuńcza przebiega według innego modelu relacji kapitał stały-kapitał zmienny, choć jest co najmniej tak samo istotna dla przebiegu ,produkcji człowieka przez człowieka”.

Druga zasadnicza sprzeczność polega na podważaniu przez proces akumulacji kapitalizmu kognitywnego jego własnych warunków możliwości. Wszystkie trzy funkcje kapitału finansowego prowadzą do demontażu procesów i instytucji, które umożliwiły 
ukonstytuowanie się kapitalizmu kognitywnego i gwarantuja jego efektywność. Po pierwsze, akumulacja wartości w postaci wartości giełdowej spółki oraz w innych aktywach „niematerialnych” (a nie w środkach produkcji) wymusza proliferację aparatów gwarantujących „własność” konkretnych programów, danych, kodów, rozwiązań itd. Niezbędna jest bowiem identyfikacja firmy, której tożsamość sprowadza się czasami do logo oraz zestawu patentów, praw własności intelektualnej i aktywów finansowych. Warunkiem akumulacji wartości w kapitalizmie kognitywnym są zatem rozwiązania techniczno-prawne, które jednocześnie ograniczają wydajność całego systemu. Im bowiem swobodniejszy obieg wiedzy i informacji w sieciach komunikacji i uczenia się, tym bardziej są one produktywne. Wiąże się to z drugą funkcją kapitału finansowego: zasada shareholder value w powiązaniu z niestabilnym charakterem kapitalizmu kognitywnego redukuje do minimum konieczność inwestycji w umiejętności pracowników (zwłaszcza tych nienależących do ścisłego „rdzenia” firmy). Pierwszeństwo zysku inwestorów oznacza maksymalne nakierowanie na rentowność inwestycji i w dużym stopniu redukuje możliwość planowania rozwoju w perspektywie wieloletniej. Jednocześnie jednak to kapitał stały ucieleśniony w pracownikach jest czynnikiem decydującym o produktywności. Brak możliwości długookresowego planowania ich rozwoju pogłębia tylko niestabilność całego systemu (trudno bowiem wprowadzić efekt pozytywnej spirali, gdzie inwestycje w kapitał stały przekładałyby się na zwiększenie produktywności).

Tym samym przechodzimy do sprzeczności powodowanej trzecia funkcja kapitału finansowego: prywatyzacja struktur reprodukcji społecznej odbiera stabilizację rozwoju kapitału stałego również poza strukturami przedsiębiorstw. W języku zaproponowanym przez Marazziego można powiedzieć, że przeniesienie oszczędności i ubezpieczeń społecznych na rynki finansowe (np. w postaci polskich OFE) ograniczyło możliwość amortyzacji kapitału stałego w kapitalizmie kognitywnym przez instytucje państwowe. Ten sam mechanizm dotyczy prywatyzacji instytucji szkolnictwa wyższego. Bez możliwości stabilnego rozwijania „wiedzy milczącej” zarówno w ramach przedsiębiorstw, jak i w ramach instytucji publicznych, ,intelekt powszechny" będzie tracił swoja produktywność, co w konsekwencji będzie destabilizowało cały reżim akumulacji.

Wszystkie te sprzeczności wynikają z fundamentalnego antagonizmu tkwiącego w samym sercu reżimu akumulacji kapitalizmu kognitywnego: podstawowym dla wszelkiej postaci kapitalizmu przeciwieństwem wartości użytkowej i wartości wymiennej. Produkcja wiedzy - od wiedzy milczącej po aplikację wiedzy skodyfikowanej - jest procesem o dużo większym poziomie skomplikowania niż jakikolwiek inny rodzaj społecznej produkcji. „Gospodarka oparta na wiedzy” godna tego miana powinna wytwarzać odpowiednie warunki do każdego z momentów tego procesu. Znaczące uzależnienie rozwoju tej gospodarki od kapitału finansowego i powiązanie innowacji technologicznych z reakcją na kryzys kapitalizmu przemysłowego sprawiły jednak, że emancypacyjny rozwój technologii przetwarzania 
i dystrybucji informacji oznaczał jednocześnie narzucenie nowych stosunków społecznych determinowanych przez logikę wartości wymiennej. Istotne jest jednak, by umieć oddzielić rozwój technologii cyfrowych od mechanizmów reżimu akumulacji kapitalizmu kognitywnego. Walka przeciwko nowym metodom podporządkowania i wyzysku społecznego nie powinna przybrać postaci walki przeciwko nowym technologiom, postępujacej informatyzacji i automatyzacji oraz wzrastającej roli wiedzy w procesach produkcji (co czasami można zaobserwować wśród niektórych progresywnych teorii rozwoju, nawołujących np. do reindustrializacji i powrotu do przemysłu, oczywiście w bardziej „zielonej” wersji). Kreślenie projektów rozwoju społeczno-gospodarczego dla krajów w rodzaju Polski, które nie moga liczyć na stały dopływ kapitału finansowego, jak to ma miejsce w przypadku USA, nie powinno być oparte na modelach, które wykształciły się w ramach finansowych gospodarek produkcji wiedzy. Oczekiwanie na tego rodzaju rozwój napędzany inwestycjami kapitału finansowego doprowadzi raczej do utrwalenia się podziału na centrum i peryferie niż „nadgonienia” gospodarek opartych na wiedzy w krajach centrum. Wartość wytwarzaną przez pracę kognitywną można bowiem przechwytywać w wymiarze globalnym bez rozwijania lokalnych warunków reprodukcji żywej wiedzy. Celem powinno być wykorzystywanie potencjału tkwiącego w intelekcie powszechnym i wszelkich wytwarzanych przez niego modelach otwartej kooperacji w połączeniu ze zmiana polityki finansowej państwa (np. przez wprowadzenie dochodu podstawowego) oraz, a może przede wszystkim - walka przeciwko czynnikowi determinującemu niestabilne mechanizmy akumulacji w kapitalizmie kognitywnym, a więc niekontrolowanemu już praktycznie przez nikogo kapitałowi finansowemu ${ }^{26}$.

26 Tekst ten jest wynikiem licznych dyskusji, które na temat pracy niematerialnej, nowych form produkcji, intelektu powszechnego oraz kapitalizmu kognitywnego prowadziłem na przestrzeni ostatnich paru lat. Wszystkich osób, dzięki którym wykształciło się moje spojrzenie na te problemy, nie sposób tutaj wymienić. Najwięcej dały mi dyskusje w ramach licznych seminariów organizowanych przez środowisko „Praktyki Teoretycznej”. Szczególne podziękowania za wspólną pracę nad ostateczną wersją tekstu chciałbym złożyć Sylwii Breczko, Krystianowi Szadkowskiemu oraz Maciejowi Szlinderowi. Za wszystkie niedociąnięcia, błędy i niejasności odpowiada oczywiście autor. 


\section{Wykaz literatury}

Aglietta, Michel. 1997. Régulation et crises du capitalisme. Paris: Editions Odile Jacob.

Aglietta, Michel, i Antoine Rebérioux. 2004. Dérives du capitalism financier. Paris: Albin Michel.

Amin, Ash (red.). 1994. Post-Fordism: A Reader. Oxford: Blackwell Publishing.

Bednarek, Joanna. 2011. „Życie jako moc deterytorializacji. Pragnienie-produkcja i żywa praca I - Deleuze i Guattari." Praktyka Teoretyczna 3: 161-172.

Benkler, Yochai. 2008. Bogactwo sieci. Jak społeczna produkcja żmienia rynek i wolność. Tłum. Rafał Próchniak. Warszawa: Wydawnictwa Adamickie i Profesjonalne.

Boyer, Robert. 2002. La croissance, début du siècle: De l'octet au gene. Paris: Albin Michel.

Bowring, Finn. 2004. „From the Mass Worker to the Multitude: A Theoretical Contextualization of Hardt and Negri's Empire." Capital \& Class 83: 101-132.

Brouillette, Sarah. 2009. „Creative Labor.” Mediations. Journal of the Marxist Literary Group 24(2).

Browning, E.S., Steven Russolilo i Jessica Vascellaro. 2012. „Apple Now Biggest-Ever U.S. Company." Wall Street Journal. http://www.wsj.com/articles/SB10000872396390443855804577601773524745182

Cillario, Lorenzo. 1990. „Il capitalismo cognitivo: Saper, sfruttamento e accumulazione dopo la rivoluzione informatica." W Transformazione e persistenza. Saggi sulla storicità, red. Lorenzo Cillario, Roberto Finelli, Augusto Illuminati, Gianfranco La Grassa, Constanzo Preve. Milan: FrancoAngeli.

Cillario, Lorenzo. 1991. „Nel tempo del “capitalismo cognitivo’.” Critica marxista 4-5.

Corsani, Antonella, Patrick Dieuaide, Maurizio Lazzarato, Jean-Marie Bonnier, Yann MoulierBoutang, Bernard Paulré i Carlo Vercellone. 2001. „Le Capitalisme cognitif comme sortie de la crise du capitalisme industriel. Un programme du recherché." http://www.utc.fr/oi2/Textes_support_interventions/Paulr $\%$ E9\%20et $\% 20$ alii $\% 20$ $\% 20$ Le $\% 20$ capitalisme $\% 20$ cognitif $\% 20$ comme $\% 20$ sortie $\% 20 \mathrm{de}^{2} \% 20 \mathrm{la} \% 20$ crise $\% 20 \mathrm{du}$ $\% 20$ capitalisme $\% 20$ industriel- $\% 20$ CAPITALC.PDF

Diederichsen, Diedrich. 2010. „Wartość (dodatkowa) sztuki.” Tłum. Mikołaj Ratajczak. W Robotnicy opuszczaja miejsca pracy, red. Joanna Sokołowska. Lódź: Muzeum Sztuki w Lodzi.

Dore, Ronald. 2000. Stock Market Capitalism: Welfare Capitalism. Japan and Germany versus the Anglo-Saxons. New York: Oxford University Press.

Drucker, Peter. 2002. Managing in the Next Society. New York: Truman Talley Books.

Foray, Dominique i Bengt-Âke Lundvall (red.). 1996. Employment and Growth in the KnowledgeBased Economy. Paris: OECD.

Fortunati, Leopoldina. 2007. „Immaterial Labor and Its Machinization.” ephemera 7(1): 139_ 157.

The Economist. 2014. „The Third Great Wave.” http://www.economist.com/sites/default/files/20141004_world_economy.pdf

Freeman, Christopher i Carlota Perez. 1988. „Structural Crisis of Adjustment, Business Cycle and Investment Behaviour." W Technical Change and Economic Theory, red. Giovanni Dosi et al. London: Pinter.

Fumagalli, Andrea i Stefano Lucarelli. 2007. „A Model of Cognitive Capitalism: A Preliminary Analysis." European Journal of Economic and Social Systems 20(1): 117-133.

Fumagalli, Andrea i Stefano Lucarelli. 2010. „Cognitive Capitalism as Financial Economy of Production." W Cognitive Capitalism and Its Reflections in South-Eastern Europe, red. Vladimir Cvijanovic, Andrea Fumagalli i Carlo Vercellone. Frankfurt a/M: Peter Lang. 
Fumagalli, Andrea i Stefano Lucarelli. 2014. „Dochód podstawowy a wydajność w kapitalizmie kognitywnym." Tłum. Krystian Szadkowski. Praktyka Teoretyczna 2(12): 79_ 104.

Gorz, André. 2010. The Immaterial. Tłum. Chris Turner. London: Seagull Books.

Hardt, Michael i Antonio Negri. 2005. Imperium. Tłum. Adam Kołbaniuk, Sergiusz Ślusarski. Warszawa: W.A.B.

Hardt, Michael i Antonio Negri. 2012. Rzecz-pospolita” Poza wtasność prywatna i dobro publiczne. Tłum. Praktyka Teoretyczna. Kraków: korporacja ha!art.

Husson, Michel. 2011. Kapitalizm bez znieczulenia: Studia nad wspótçesnym kapitalizmem, kryzysem swiatowym i strategiq antykapitalistyczna. Tłum. Zbigniew Marcin Kowalewski. Warszawa: Instytut Wydawniczy Książka i Prasa.

Jovanovska, Nadica i Natalija Nikolovska. 2010. „The Big Trade Off of »New - Europe«: Convergence or Divergence from USA Model of Capitalism." W Cognitive Capitalism and Its Reflections in South-Eastern Europe, red. Vladimir Cvijanovic, Andrea Fumagalli i Carlo Vercellone. Frankfurt a/M: Peter Lang.

Kleiner, Dmytri. 2007. „Copyfarleft and Copyjustright.” http://www.metamute.org/editorial/articles/copyfarleft-and-copyjustright

Lazzarato, Maurizio. 2011. „Praca niematerialna.” Tłum. Lukasz Biskupski. W Robotnicy opuszrzaja miejsca pracy, red. Joanna Sokołowska. Łódź: Muzeum Sztuki w Lodzi.

Lazzarato, Maurizio. 2012. The Making of the Indebted Man. Tłum. Joshua David Jordan. Los Angeles: Semiotext(e).

Lazzarato, Maurizio i Antonio Negri. 1991. „Travail immatériel et subjectivité.” Futur Antérieur 6: 86-89.

Lerner, Josh i Jean Triole. 2002. „The Simple Economics of Open Source.” Journal of Industrial Economics 52: 197-234.

Lorey, Isabell. 2014. „Urzadzanie i samoprekaryzacja. O normalizacji wytwórców kultury”. Tłum. Piotr Juskowiak. Praktyka Teoretyczna 4(14).

Lucarelli, Stefano. 2010. „Financialization as Biopower.” W Crisis In the Globar Economy: Financial Markets, Social Struggles, and New Political Scenarios, red. Andrea Fumagalli i Sandro Mezzadra. Tłum. Jason Francis McGimsey. Los Angeles: Semiotext(e).

Lucarelli, Stefano i Carlo Vercellone. 2013. „The Thesis of Cognitive Capitalism: New Research Perspectives. An Introduction." Knowledge Cultures 1(4): 2-14.

Marazzi, Christian. 2008. Capital and Language: From the New Economy to the War Economy. Tłum. Gregory Conti. Los Angeles: Semiotext(e).

Marazzi, Christian. 2011. The Violence of Financial Capitalism. Tłum. Kristina Lebedeva, Jason Francis McGimsey. Los Angeles: Semiotext(e).

Marazzi, Christian. 2014a. „Die Amortisation der Körper-Maschine.” W Christian Marazzi, Sozialismus des Kapitals. Tłum. Thomas Atzert. Zürich: diaphanes.

Marazzi, Christian. 2014b. „Der Sozialismus des Kapitals.” W Christian Marazzi, Sozialismus des Kapitals. Tłum. Thomas Atzert. Zürich: diaphanes.

Marks, Karol. 1968. Kapitat: Krytyka ekonomii politycznej. Tom pierwssy. Warszawa: Książka i Wiedza.

Marks, Karol. 1986. Zarys krytyki ekonomii politycznej. Tłum. Zygmunt Jan Wyrozembski. Warszawa: Książka i Wiedza.

Moulier-Boutang, Yann. 1996. „La revanche des externalités. Globalisation des économies, externalités, mobili, transformation de l'économie et de l'intervention publique." Futur Antérieur 39-40: 39-70.

Moulier-Boutang, Yann. 2011. Cognitive Capitalism. Tłum. Ed Emery. Cambridge: Polity Press. 
Orléan, André. 2012. „Knowledge in Finance: Objective Value versus Convention.” http://www.parisschoolofeconomics.com/orleanandre/depot/publi/knowledge0606.pdf

Pasqualle, Frank. 2014. The Black Box Society: The Secret Algorithms That Control Money and Information. Cambridge, London: Harvard University Press.

Pasquinelli, Matteo. 2009. „Google's PageRank Algorithm: A Diagram of the Cognitive Capitalism and the Rentier of the Common Intellect." W Deep Serach: The Politics of Search Beyond Google, red. Konrad Becker i Felix Stalder. London: Transaction Publisher.

Pasquinelli, Matteo. 2011. „Maszynowa wartość dodatkowa a praca informacji: uwagi o ekonomii politycznej maszyny Turinga.” Tłum. Krystian Szadkowski. W Wieczna radość: Ekonomia polityczna społeçnej kreatywności, red. Michał Kozłowski, Agnieszka Kurant, Jan Sowa, Krystian Szadkowski i Kuba Szreder. Warszawa: Fundacja Nowej Kultury Bęc Zmiana.

Pastor, Lubos i Pietro Veronesi. 2006. „Was There a Nasdaq Bubble In The Late 1990s?” Journal of Financial Economics 81: 61-100.

Ratajczak, Mikołaj. 2014. „Sztuka i praca. Od ekonomii politycznej produkcji artystycznej do krytycznej filozofii współczesnych form pracy.” W Skutecz̧ność squtuki, red. Tomasz Załuski. Łódź: Muzeum Sztuki w Lodzi.

Rossi-Landi, Ferruccio. 1968. Il linguaggio come lavoro e come mercato: Una teoria della produzione e dell'alienazione linguistiche, Milano: Bompiani.

Rullani, Enzo. 2014a. Economia della conoscenza: Creatività e valore nel capitalismo delle reti. Roma: Carocci.

Rullani, Enzo. 2014b. La fabbrica dell'immateriale. Produrre valore con la conoscenza. Roma: Carocci. Standing, Guy. 2014. Prekariat. Nowa niebezpieczna klasa. Tłum. Krzysztof Czarnecki, Paweł Kaczmarski, Mateusz Karolak. Warszawa: Wydawnictwo Naukowe PWN.

Szadkowski, Krystian. 2013. „Postoperaistyczne lektury Marksowskiego Fragmentu o mas zynach w świetle krytyki." Praktyka Teoretyczna 3(9): 63-110.

Szlinder, Maciej. 2014. „Od sprawiedliwości do warunku transformacji: Dochód podstawowy w kapitalizmie kognitywnym." Praktyka Teoretyczna 2(12): s. 105-142.

Terranova, Tiziana. 2000. „Free Labor: Producing Culture in the Digital Economy.” Social Text 63: 33-58.

Terranova, Tiziana. 2010. „New Economy, Financialization and Social Production in the Web 2.0." W Crisis In the Globar Economy: Financial Markets, Social Struggles, and New Political Scenarios, red. Andrea Fumagalli i Sandro Mezzadra. Tłum. Jason Francis McGimsey. Los Angeles: Semiotext(e).

Therborn, Göran. 2015. Nierówność, która zabija: Jak globalny wzৃrost nierówności nisz̧̧̧y życie milionów i jak z tym walcsyć. Tłum. Paweł Tomanek. Warszawa: Wydawnictwo Naukowe PWN.

Urry, John. 2014. Offshoring. London: Polity Press.

Vercellone, Carlo (red.). 2003. Sommer-nous sortis du capitalisme industrielle? Paris: La Dispute.

Vercellone, Carlo. 2005. „A Hypothesis of Cognitive Capitalism.” https://hal-paris1.archivesouvertes.fr/file/index/docid/273641/filename/The_hypothesis_of_Cognitive_Capitali smhall.pdf

Vercellone, Carlo. 2007. „From Formal Subsumtion to General Intellect: Elements for a Marxist Reading of the Thesis of Cognitive Capitalism." Historical Materialism 15: 13-36.

Vercellone, Carlo. 2008. „Wages, Rent and Profit: The New Articulation of Wages, Rent and Profit in Cognitive Capitalism.” http://www.generation-online.org/c/fc_rent2.htm 
Vercellone, Carlo. 2014. „Crisi e instituzioni del welfare: Nuove note sul capitalismo cognitivo." W Gli algoritmi del kapitale: Accelerazionismo, macchine della conoscen za e autonomia del comune, red. Matteo Pasquinelli. Verona: ombre corte.

Vieira, Miguel Said i Primavera De Filippi. 2014. „Between Copyleft and Copyfarleft: Advance Reciprocity for the Commons." Journal of Peer Production 4. http://www.metamute.org/editorial/articles/copyfarleft-and-copyjustright

Vinci, Paolo. 2014. „Abstrakcja określona.” W Marks. Nowe perspektywy, red. Libera Università Metropolitana. Tłum. Sławomir Królak. Warszawa: Wydawnictwo Naukowe PWN.

Virno, Paolo. 1992. „Quelques notes à propos du general intellect.” Futur Antérieur 10: 45-53. Virno, Paolo. 2003. Quando il verbo si fa carve. Torino: Bollati Boringhieri.

Virno, Paolo. 2014. „Kooperacja.” W Marks. Nowe perspektywy, red. Libera Università Metropolitana. Tłum. Sławomir Królak. Warszawa: Wydawnictwo Naukowe PWN.

Zanini, Adelino i Ubaldo Fanini (red.). 2001. Lessico postfordista: Dizionario di idee della mutazione. Milano: Feltrinelli. 
Mikołaj Ratajczak - filozof, członek redakcji czasopisma naukowego "Praktyka Teoretyczna", w latach 2012-2015 wydawca filozofii i nauk społecznych w Wydawnictwie Naukowym PWN. Autor publikacji dotyczących współczesnej włoskiej filozofii politycznej oraz teorii marksistowskiej, w szczególności teoriom pracy niematerialnej i biopolitycznej. Współtłumacz Rzecz-pospolitej Hardta i Negriego, autor przekładu Rezultatów bezpośredniego procesu produkecji Karola Marksa na język polski, a także szeregu tłumaczeń tekstów współczesnych teoretyków i teoretyczek postoperaistycznych. Współredaktor dwóch tomów poświęconych myśli Giorgio Agambena. W Instytucie Filozofii i Socjologii PAN przygotowuje książkę poświęconą współczesnej włoskiej filozofii politycznej jako politycznej filozofii życia, języka i pracy.

\section{DANE ADRESOWE:}

Szkoła Nauk Społecznych PAN

Nowy Świat 72

00-330 Warszawa

EMAIL: mikolaj.ratajczak@gmail.com

CYTOWANIE: Ratajczak, Mikołaj. 2015. Wprowadzenie do teorii kapitalizmu kognitywnego: kapitalizm kognitywny jako reżim akumulacji. „Praktyka Teoretyczna” 1(15): 57-94.

DOI: $10.14746 /$ prt.2015.1.2

FINANSOWANIE: Artykuł powstał w ramach projektu „Ekonomia literatury”. Projekt został sfinansowany ze środków Narodowego Centrum Nauki przyznanych na podstawie decyzji nr DEC-2012/05/D/HS2/03589.

\section{AUTHOR: Mikołaj Ratajczak}

TITLE: Introduction to the theory of cognitive capitalism: cognitive capitalism as a regime of accumulation

ABSTRACT: Article presents a historic, systematic and critical introduction to the theory of cognitive capitalism. It reconstructs the most important positions and debates within the field, from the first publications on the questions of immaterial labor and post-Fordism to the analyses of the financial crisis of 2001 to the recent publications of theoreticians of cognitive capitalism. It systematizes the debates on the hypothesis of cognitive capitalism, from the increasing role of the externalities and rent to the transformation of general intellect to the emergence of the new forms of value and the new mechanisms of its accumulation. It is this last issues, the new mechanisms of value accumulation, that constitutes the main interest of the 
article, which tries to present the functions of the financial capital in the formation of cognitive capitalism as a regime of accumulation and to analyze cognitive capitalism not only as an unstable regime of accumulation, but also to formulate the main contradictions of cognitive capitalism.

KEYWORDS: cognitive capitalism, accumulation, value, financial capital, immaterial labor, general intellect, externalities, political economy, Vercellone, Marazzi, Moulier-Boutang 